UNIVERSIDADE ESTADUAL PAULISTA “JÚLIO DE MESQUITA FILHO" INSTITUTO DE BIOCIÊNCIAS, LETRAS E CIÊNCIAS EXATAS.

DEPARTAMENTO DE ENGENHARIA E TECNOLOGIA DE ALIMENTOS CAMPUS DE SÃO JOSÉ DO RIO PRETO

EFEITO DAS CONDIÇÕES DE CONGELAMENTO SOBRE ATRIBUTOS DE QUALIDADE DE FATIAS DE ABACAXI LIOFILIZADO

Mestranda: Ana Paula Vieira Orientadora: Prof ${ }^{a}$. Dr ${ }^{a}$. Vânia Regina Nicoletti Telis Co-orientador: Prof. Dr. Joel Fernando Nicoleti 
ANA PAULA VIEIRA

\title{
EFEITO DAS CONDIÇÕES DE CONGELAMENTO SOBRE ATRIBUTOS DE QUALIDADE DE FATIAS DE ABACAXI LIOFILIZADO
}

\author{
Dissertação apresentada ao Instituto de Biociências, Letras e Ciências \\ Exatas da Universidade Estadual Paulista "Júlio de Mesquita Filho" \\ Campus de São José de Rio Preto, para a obtenção do título de Mestre em \\ Engenharia e Ciência de Alimentos (Área de concentração: Engenharia \\ de Alimentos).
}

Orientadora: Profa. Dra. Vânia Regina Nicoletti Telis Co-orientador: Prof. Dr. Joel Fernando Nicoleti

São José do Rio Preto - SP

Janeiro 2010 
ANA PAULA VIEIRA

\title{
EFEITO DAS CONDIÇÕES DE CONGELAMENTO SOBRE ATRIBUTOS DE QUALIDADE DE FATIAS DE ABACAXI LIOFILIZADO
}

\author{
COMISSÃO JULGADORA \\ DISSERTAÇÃO PARA OBTENÇÃO DO GRAU DE MESTRE
}

Prof. Dra. Vânia Regina Nicoletti Telis

(Presidente e Orientadora - DETA/IBILCE/UNESP)

Prof. Dr. Marcos Alexandre Polizelli

(2º Examinador - Fundação Educacional de Fernandópolis)

Prof. Dr. José Antonio Gomes Vieira

( $3^{\circ}$ Examinador - DETA/IBILCE/UNESP $)$

Prof. Dr. Fábio Yamashita

(4ํㅡㄹ Examinador - DTA/UEL)

Prof. Dr. José Francisco Lopes Filho

(5ํㅡㄹ Examinador - DETA/IBILCE/UNESP)

São José do Rio Preto - SP

Janeiro 2010 


\section{DEDICATÓRIA}

Minha mãe por se constituir diferentemente enquanto pessoa, igualmente bela e admirável em essência, estímulos que me impulsionaram a buscar vida nova a cada dia, meus agradecimentos por ter aceito se privar de minha companhia pelos estudos, acolhendo meu filho com maior dedicação e carinho, concedendo a mim a oportunidade de me realizar ainda mais. 


\section{AGRADECIMENTOS ESPECIAIS}

E ofereço especialmente este trabalho a vocês, $\underline{\operatorname{Prof}^{\mathrm{a}} \text {. Dr }{ }^{\mathrm{a}} \text { Vânia Regina Nicoletti Telis, }}$ minha orientadora, um exemplo de mulher, mãe, e a você Prof. Dr. Joel Fernando Nicoleti, meu co-orientador, um exemplo de homem, amigo, que neste tempo souberam me ensinar com tamanha serenidade, sabedoria, carinho e paciência todos os meus afazeres e principalmente ouvir-me a todos meus questionamentos, pessoas que, verdadeiramente, estiveram ao meu lado.

A você Vânia pelo incentivo, simpatia e presteza no auxílio às atividades e discussões sobre o andamento e normatização desta monografia de Obtenção do Grau de Mestre, sem a qual minha monografia não teria a mesma qualidade.

E a você Prof. Dr. Joel Fernando Nicoleti pelo seu espírito inovador e empreendedor na tarefa de multiplicar seus conhecimentos. 


\section{AGRADECIMENTOS}

Primeiramente, a DEUS que sem sua presença nada seria possível, agradecendo pela oportunidade e pelo privilégio que me foi dado em compartilhar tamanha experiência e, ao freqüentar este curso, perceber e atentar para a relevância de temas que não faziam parte, em profundidade, de minha vida.

A todos os professores e seus convidados pelo carinho, dedicação e entusiasmo demonstrado ao longo do curso, e em especial aos professores Dr. José Antonio Gomes Vieira e Dr. Marcos Alexandre Polizelli por fazer parte da integralização deste trabalho.

Aos colegas de classe pela espontaneidade e alegria na troca de informações e materiais numa rara demonstração de amizade e solidariedade, em especial Alessandra de Andrade.

Aos demais idealizadores, coordenadores e funcionários do Instituto de Biociências, Letras e Ciências Exatas da Universidade Estadual Paulista "JÚLIO DE MESQUITA FILHO”. 
SUMÁRIO

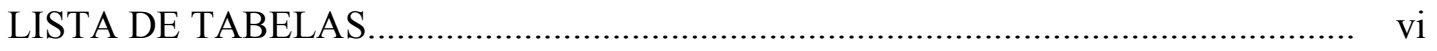

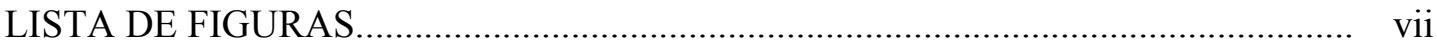

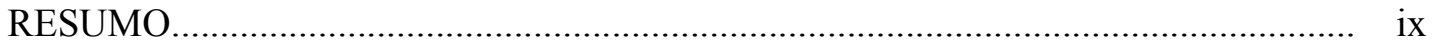

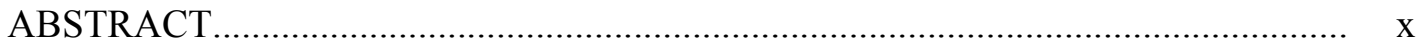

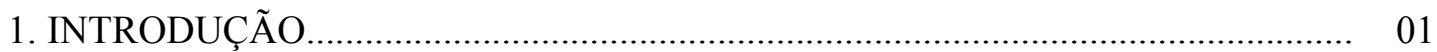

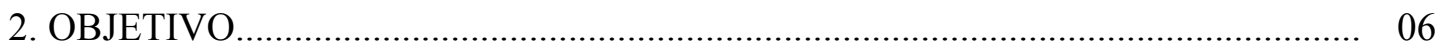

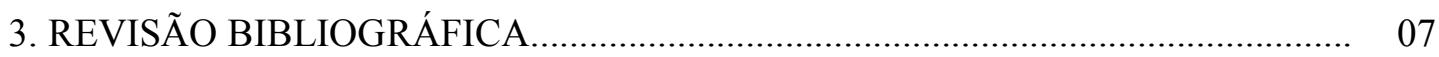

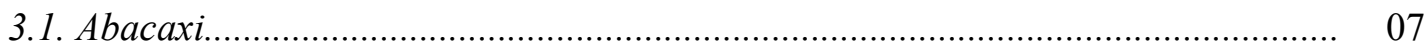

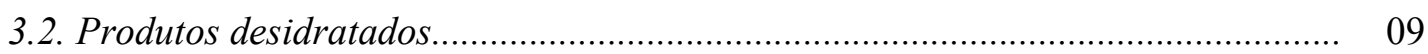

3.3. Fundamentos da secagem.................................................................................... 13

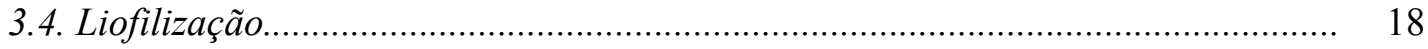

3.4.1. Estágio de congelamento..................................................................................... 22

3.4.2. Estágio de secagem primária.................................................................................... 25

3.4.3. Estágio de secagem secundaria............................................................................... 26

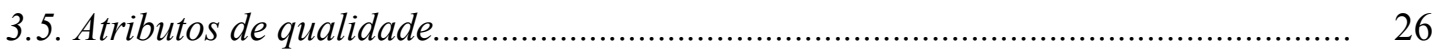

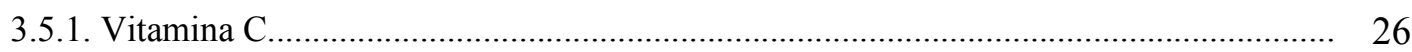

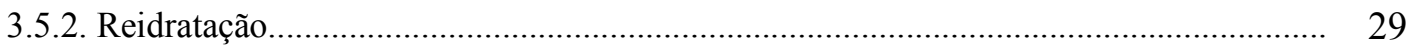

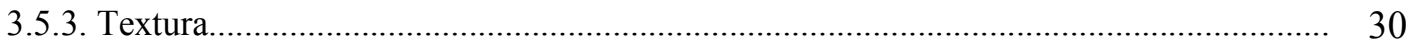

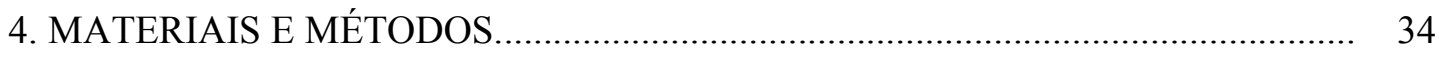

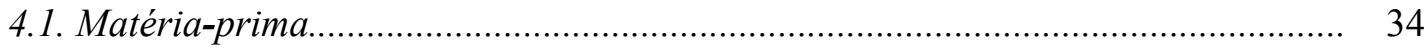

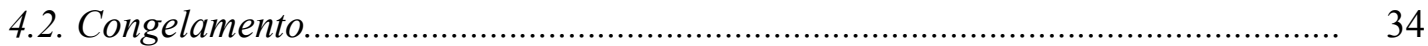

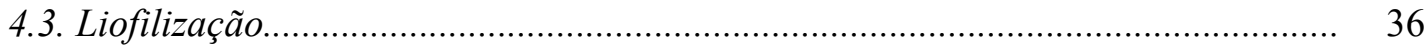

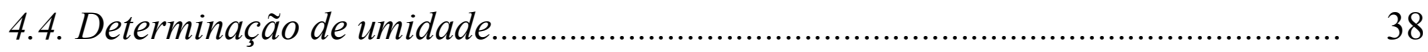

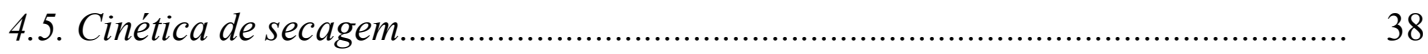

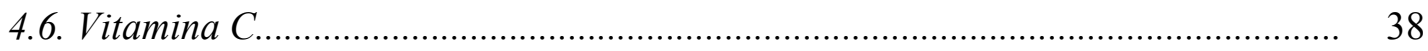

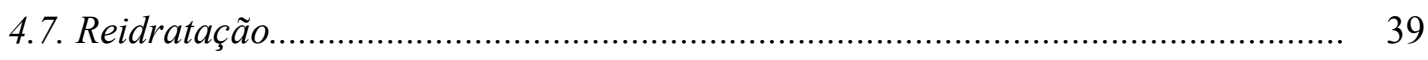

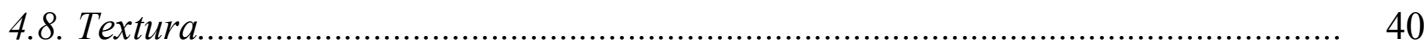

5. RESULTADOS E DISCUSSÕES................................................................... 42

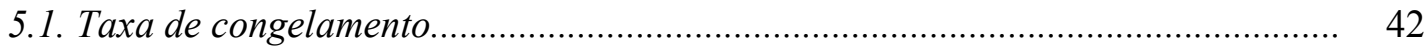

5.2. Cinética de secagem................................................................................... 47

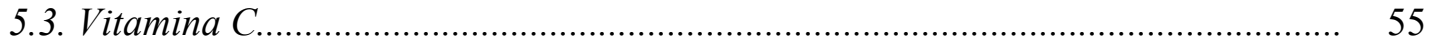




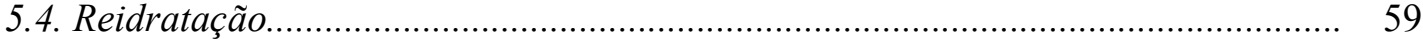

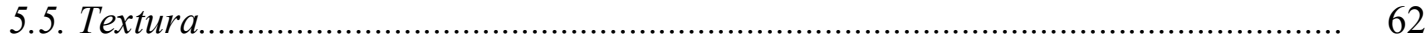

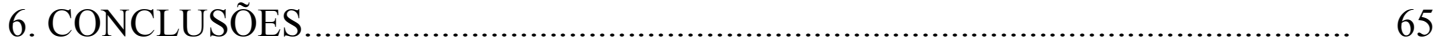

7. SUGESTÕES PARA TRABALHOS FUTUROS..................................................... 66

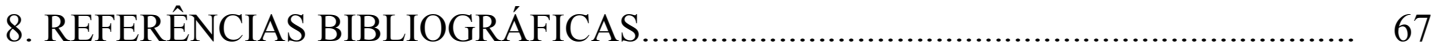




\section{LISTA DE TABELAS}

Tabela 1. Composição química do abacaxi da variedade Smooth Cayenne.

Tabela 2. Alterações da qualidade de produtos alimentícios durante a secagem (Strumillo e Adamiec, 1996)

Tabela 3. Planejamento experimental para o congelamento das fatias de abacaxi..........

Tabela 4. Taxas de congelamento calculadas pela Equação (4) para fatias de abacaxi de diferentes espessuras, congeladas em diferentes temperaturas.

Tabela 5. Análise de variância dos dados de taxa de congelamento em função da espessura da fatia e da temperatura de congelamento.

Tabela 6. Valores de difusividade efetiva obtidos pelo ajuste da $2 \mathrm{a}$ Lei de Fick linearizada ao período inicial da liofilização $(\mathrm{t} \leq 7,5 \mathrm{~h})$.

Tabela 7. Análise de variância dos dados de difusividade efetiva em função da espessura da fatia e da temperatura de congelamento.

Tabela 8. Conteúdo de Vitamina $\mathrm{C}$ antes e após a liofilização em função da temperatura de congelamento e as espessuras das amostras.

Tabela 9. Análise de variância dos dados de retenção de vitamina $\mathrm{C}$ em função da espessura da fatia e da temperatura de congelamento.

Tabela 10. Capacidade de reidratação de fatias de abacaxi liofilizadas submetidas a diferentes condições de congelamento e condicionadas a $\mathrm{a}_{\mathrm{w}}=0,432$.

Tabela 11. Análise de variância dos dados de reidratação em função da espessura da fatia e da temperatura de congelamento.

Tabela 12. Capacidade de dureza de fatias de abacaxi liofilizadas submetidas a diferentes condições de congelamento e condicionadas a $\mathrm{a}_{\mathrm{w}}=0,432$.

Tabela 13. Análise de variância dos dados de dureza em função da espessura da fatia e da temperatura de congelamento. 


\section{LISTA DE FIGURAS}

Figura 1. Curvas típicas de evolução da temperatura e da umidade do produto durante a secagem (PARK; YADO; BROD, 2001).

Figura 2. Diagrama de fases da água pura.................................................................... 19

Figura 3. Estrutura básica de um liofilizador (VITAL; LUZ; LIMA, 2003)....................... 20

Figura 4. Estágios do processo de liofilização..................................................................... 21

Figura 5. Curva generalizada obtida através de um teste de TPA (TELIS;

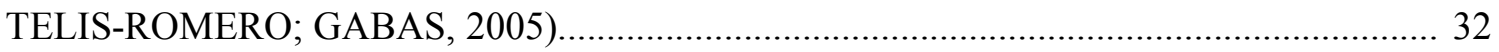

Figura 6. Liofilizador utilizado na realização dos ensaios de secagem............................... 36

Figura 7. Disposição das fatias nas bandejas do liofilizador............................................ 37

Figura 8. Texturômetro e probe utilizado nos ensaios de TPA das amostras liofilizadas...... 41

Figura 9. Perfis da temperatura no centro das fatias de diferentes espessuras congeladas

$\mathrm{a}-14{ }^{\circ} \mathrm{C}$

Figura 10. Perfis da temperatura no centro das fatias de diferentes espessuras congeladas a $-24{ }^{\circ} \mathrm{C}$.

Figura 11. Perfis da temperatura no centro das fatias de diferentes espessuras congeladas a $-34{ }^{\circ} \mathrm{C}$.

Figura 12. Efeitos da espessura das fatias e da temperatura de congelamento sobre a taxa de congelamento

Figura 13. Curvas de secagem de fatias de diferentes espessuras congeladas à temperatura $14{ }^{\circ} \mathrm{C}$

Figura 14. Curvas de secagem de fatias de diferentes espessuras congeladas à temperatura $24{ }^{\circ} \mathrm{C}$

Figura 15. Curvas de secagem de fatias de diferentes espessuras congeladas à temperatura

$34{ }^{\circ} \mathrm{C}$

Figura 16. Ajustes da Equação (2) às curvas de secagem à temperatura de $-14{ }^{\circ} \mathrm{C}$ para $t \leq 7,5 \mathrm{~h}$ 50

Figura 17. Ajustes da Equação (2) às curvas de secagem à temperatura de $-24{ }^{\circ} \mathrm{C}$ para $t \leq 7,5 \mathrm{~h}$.

Figura 18. Ajustes da Equação (2) às curvas de secagem à temperatura de $-34{ }^{\circ} \mathrm{C}$ para $t \leq 7,5 \mathrm{~h}$. 51

Figura 19. Efeitos da espessura das fatias e da temperatura de congelamento sob 
difusividade efetiva do período inicial da liofilização $(t \leq 7,5 \mathrm{~h})$

Figura 20. Conteúdo de vitamina $C$ experimental nos abacaxis in natura utilizados nos ensaios de liofilização.

Figura 21. Efeitos da espessura das fatias e da temperatura de congelamento sobre a retenção de vitamina $\mathrm{C}$ durante a liofilização.

Figura 22. Efeitos da espessura das fatias e da temperatura de congelamento sobre o índice de reidratação das fatias de abacaxi liofilizadas e condicionadas a $\mathrm{a}_{\mathrm{w}}=0,432$ 61

Figura 23. Efeitos da espessura das fatias e da temperatura de congelamento sobre a dureza das fatias de abacaxi liofilizadas e condicionadas em $\mathrm{a}_{\mathrm{w}}=0,432$ 


\section{RESUMO}

O uso de novas tecnologias de processamento, as quais permitem a manutenção dos atributos de qualidade do produto em níveis mais próximos daqueles observados na matériaprima in natura, tem permitido a obtenção de frutas desidratadas de aspecto sensorial apreciado pelos consumidores e contribuído para que sua disponibilidade se estenda para além dos períodos de safra, permitindo o consumo em qualquer período do ano. Entre os processos de desidratação que resultam em produtos de bons atributos sensoriais e nutritivos destaca-se a liofilização, onde a separação da água é baseada no fenômeno de sublimação. Considerando que as condições de congelamento exercem influência sobre as propriedades físicas e sobre os atributos sensoriais e nutritivos dos produtos liofilizados, neste trabalho foi estudada a liofilização de fatias de abacaxi (Ananas comosus) da variedade Smooth Cayenne, avaliandose os efeitos da temperatura de congelamento das amostras $\left(-14,-24\right.$ e $\left.-34{ }^{\circ} \mathrm{C}\right)$ e da espessura das fatias $(0,5,1,0$, e $1,5 \mathrm{~cm})$ sobre a taxa de congelamento, cinética de secagem e sobre alguns atributos de qualidade (textura, reidratação e retenção da vitamina $\mathrm{C}$ ) do produto final desidratado. Os resultados mostraram que existe uma forte dependência da cinética de secagem e dos atributos de qualidade do produto liofilizado, fatias de abacaxi, em função das condições utilizadas durante a etapa de congelamento. A taxa de congelamento, a difusividade efetiva da água no período inicial da liofilização, a retenção de vitamina $\mathrm{C}$, o índice de reidratação e a dureza das amostras foram afetados significativamente, a um nível de $95 \%$ de significância, pela temperatura de congelamento e espessura das fatias de abacaxi. 


\begin{abstract}
The use of new processing technologies, which permit keeping the quality attributes of the product at similar levels of those observed in the raw material, has permitted to obtain dehydrated fruits with sensorial aspects appreciated by consumers and contributed to extend their availability for periods beyond their harvest season, allowing their consumption during the whole year. Among the dehydration processes that result in products of good sensorial and nutritional attributes, the freeze drying, in which the water separation is based on the sublimation phenomenon, has an outstanding position. Taking into account that the freezing conditions exert influence on the physical properties and on the quality and nutritional attributes of freeze dried products, in this work the freeze drying of pineapple (Ananas comosus) slices of the Smooth Cayenne variety was studied, evaluating the effects of the samples' freezing temperature $\left(-14,-24\right.$ e $\left.-34{ }^{\circ} \mathrm{C}\right)$ and of the slices' thickness $(0,5,1,0$, e 1,5 $\mathrm{cm}$ ) on the freezing rate, drying kinetics and on some quality attributes (texture, rehydration, and vitamin $\mathrm{C}$ retention) of the final dehydrated product. The results showed that there is and strong dependence of the drying kinetics and of the quality attributes of freeze dried product, pineapple slices, as functions of the conditions used during the freezing step. The freezing rate, the water effective diffusivity at the initial period of freeze drying, the vitamin $\mathrm{C}$ retention, the rehydration index and the hardness of the samples were significantly affected, at a level of $95 \%$ of significance, by the freezing temperature and by the pineapple slices thickness.
\end{abstract}




\section{INTRODUÇÃO}

A aplicação da engenharia de alimentos tem como principal resultado social evitar a desnutrição generalizada, favorecer uma maior qualidade de vida e ter acesso a uma variedade de alimentos nutritivos e de baixo custo. Com a projeção do aumento populacional, a tecnologia de alimentos é indispensável para assegurar a disponibilidade de alimentos (LUND, 2002).

Nos últimos anos tem havido uma maior preocupação, por parte dos consumidores, em relação à qualidade nutricional dos alimentos, tendo em vista que a sociedade moderna, na qual não se distingue mais a hierarquia patriarcal sobre a matriarcal, inclui cada vez mais a mulher no ambiente de trabalho fora do lar, tendo como conseqüência menor tempo dedicado aos afazeres domésticos, o que implica na busca de produtos de maior conveniência, que tragam facilidade no manuseio e preparo, e com pequena ou nenhuma perda de atributos sensoriais.

As frutas e hortaliças desempenham um importante papel na dieta humana, sendo fontes indispensáveis de nutrientes essenciais como vitaminas, sais minerais e fibras para a alimentação humana, além de introduzirem cor, sabor, aroma e variedade ao rol de alimentos disponíveis. O cálcio e o ferro são os principais sais minerais encontrados nas frutas, todas as frutas possuem vitaminas, sendo que, as frutas tropicais se destacam por conterem maior quantidade (EMPRAPA, 2009). Porém, grandes perdas são detectadas na agricultura na maioria dos países tropicais em desenvolvimento, onde a abundância natural de frutas tropicais frescas leva, com freqüência, a um excedente com respeito à demanda local. Logo, apenas uma quantidade limitada de produtos processados a partir destes frutos é produzida e comercializada. 
Esse panorama poderia ser melhorado pela agregação de valor a tais produtos, através de seu processamento. Sendo assim, um número considerável de métodos alternativos de processamento de alimentos vem sendo objetivo de pesquisas, fazendo com que a fruta que antes era consumida só em sua época de safra, hoje passe a ser consumida em qualquer período do ano.

A desidratação é, provavelmente, o método mais antigo de preservação dos alimentos, sendo bastante adequado a países com grande potencial agroindustrial como o Brasil. No entanto, a secagem de produtos alimentícios não é aplicada da forma mais abrangente devido aos prejuízos causados pelo processo às características sensoriais do produto. Entre os processos de desidratação que resultam em produtos de bons atributos sensoriais e nutritivos destaca-se a liofilização, onde a separação da água é baseada no fenômeno de sublimação. Devido à ausência de água liquida e às baixas temperaturas atingidas durante o processo, a maior parte das reações de deterioração são prevenidas, levando a um produto final de excelente qualidade.

O processo de liofilização consiste em um processo de secagem do material através da sublimação da parte congelada a temperaturas baixas e sob vácuo. O desempenho do processo é fortemente dependente da escolha adequada das condições operacionais e, portanto, há necessidade de uma extensiva análise de seus efeitos no tempo de processamento e na qualidade do produto obtido. Esta tecnologia foi desenvolvida para superar as perdas de compostos responsáveis pelos aromas nos alimentos, os quais são muito susceptíveis às modalidades de processamento que empregam temperaturas elevadas como a secagem convencional (IBARZ; BARBOSA-CANOVAS, 1999). Três estágios distintos caracterizam o processo de liofilização: estágio de congelamento, estágio de secagem primária e estágio de secagem secundária. No estágio de congelamento, o material torna-se completamente sólido a temperaturas inferiores ao seu ponto de início de congelamento. No estágio de secagem 
primária a água congelada é removida por sublimação, originando espaços vazios no interior da matriz alimentícia que antes eram ocupados pelo gelo sublimado, tornando o alimento poroso. Entretanto, ainda podem restar quantidades significativas de água ligada no interior do produto, o que demanda um potencial adicional. A força motriz desta etapa é o leve aquecimento aplicado durante o estágio de secagem secundária, em que ocorre a dessorcão da água ligada (SNOWMAN, 1997).

A diferença entre os métodos de congelamento utilizados reside principalmente na velocidade em que ocorre o congelamento. $\mathrm{O}$ congelamento lento é prejudicial para materiais formados por células, pois propicia a formação de grandes cristais de gelo que, após a sublimação da água ou da substância aquosa, pode causar prejuízos mecânicos à estrutura das células. No entanto o congelamento rápido é resultado de uma queda brusca de pressão ou temperatura e, em resposta a esta espécie de choque, pequenos cristais de gelo são formados e distribuídos uniformemente sem afetar a estrutura da célula (BOSS, 2004).

O emprego da liofilização está crescendo, principalmente nas indústrias farmacêuticas, biotecnológicas, de alimentos e em indústrias de processamento químico. A escolha pelo processo de liofilização se deve aos bons atributos de qualidade apresentados pelo produto desidratado, podendo servir como ingrediente em alimentos formulados propiciando a estes um alto valor nutricional agregado além de potencializar a exportação.

O abacaxi, devido à sua excelente qualidade sensorial, beleza e à existência da coroa, desde há muito faz jus ao cognome de rei dos frutos. É um autêntico produto de regiões tropicais e subtropicais, altamente consumido em todo o mundo, sobretudo sob a forma de compotas e sucos. Além disso, também se presta para fabricação de doces cristalizados, geléias, sorvetes, cremes, gelatinas e pudins (TODA FRUTA, 2008). No Brasil, a oferta dessa cultura vem crescendo a taxas superiores à média mundial e o país tem o potencial de, em breve, tornar-se o líder mundial na produção da fruta, contribuindo com $10 \%$ da produção 
mundial (EMBRAPA, 2005). Existem centenas de variedades de abacaxi, no entanto, comercialmente são considerados como os mais importantes o Pérola, o Amarelo comum ou Boituva e o Smooth Cayenne (Havaiano).

As cultivares Smooth Cayenne e Pérola lideram o mercado brasileiro, sendo esta última bastante apreciada para o consumo tanto in natura como na forma de produtos industrializados, pois apresenta ótima qualidade organoléptica, decorrente do sabor e aroma característicos, sendo boa fonte de vitaminas, açúcares e fibra, além de auxiliar no processo digestivo e atender às preferências do consumidor brasileiro graças às suas características de polpa suculenta e adocicada. O cultivar Smooth Cayenne é o mais plantado no mundo, correspondendo a 70\% da produção mundial. Suas características de sabor e aroma, com um bom equilíbrio entre acidez e açúcar, tornam este cultivar muito apreciado em nível de industrialização e/ou exportação (ABANORTE, 2009). De alto valor nutricional, a polpa do abacaxi é energética e contém boas quantidades das vitaminas A, B1 e C, além de atender a algumas exigências industriais como consistência firme, coloração amarela intensa, maior acidez e formato cilíndrico, que lhe confere maior facilidade de embalagem (SAVITCI et al., 1996).

O interesse pela desidratação tem aumentado no sentido de desenvolver métodos de secagem de frutas que resultem em produtos com características especiais de reconstituição instantânea, de grande importância em alimentos de preparo rápido. A demanda por esta alta qualidade do produto desidratado, fornecendo características semelhantes às do produto fresco - o que se traduz na facilidade e rapidez de reidratação e na retenção dos nutrientes - implica na necessidade de pesquisa básica sobre a influência das condições de secagem na qualidade dos alimentos desidratados.

A liofilização é um processo recomendado para materiais sensíveis a altas temperaturas, apresentando como principais vantagens o pequeno encolhimento e baixas taxas 
de reações de degradação do material, o que não ocorre nas operações de secagem convencionais. Por outro lado, ainda são poucos os estudos sobre os efeitos das condições de liofilização sobre a cinética de secagem e atributos de qualidade de frutas liofilizadas. 


\section{OBJETIVOS}

Com base nas considerações acima, o presente trabalho tem como objetivos:

- determinar a influência da espessura e da temperatura de congelamento de fatias de abacaxi sobre as taxas de congelamento;

- determinar a cinética de liofilização de fatias de abacaxi submetidas a diferentes taxas de congelamento;

- verificar a influência da espessura e da temperatura de congelamento sobre a textura, o índice de reidratação e a retenção de vitamina $\mathrm{C}$ de fatias de abacaxi liofilizadas. 


\section{REVISÃO BIBLIOGRÁFICA}

\subsection{Abacaxi}

As frutas e hortaliças desempenham um importante papel na dieta humana, sendo fontes indispensáveis de nutrientes essenciais como vitaminas, minerais e fibras, além de serem responsáveis pela introdução de cor, sabor, aroma e variedade ao rol de alimentos disponíveis. Entretanto, devido ao seu alto teor de água (acima de 80\%) são altamente perecíveis.

Uma das frutas tropicais mais populares do mundo, o abacaxi (Ananas comosus) é muito apreciado em todos os países tropicais, devido à sua polpa suculenta, saborosa, ligeiramente ácida e refrescante. Ao lado das qualidades organolépticas que o distinguem universalmente, encontram-se seus altos valores dietéticos (Tabela 1), comparáveis aos das melhores frutas tropicais. As vitaminas presentes são numerosas, podendo ser considerado como boa fonte de vitamina A $\left(0,3 \mathrm{mg}\right.$ de caroteno para $100 \mathrm{~g}$ de suco), $\mathrm{B}_{1}$ e uma fonte aceitável de vitamina C (em média 8,5 mg por 100 g) (MEDINA et al., 1978).

O abacaxi, extensivamente cultivado em todos os países tropicais pelos seus excelentes frutos, é segundo a maioria dos naturalistas e historiadores, planta originária das Américas tropical e subtropical, e muito provavelmente do Brasil. No Brasil são três as principais variedades cultivadas comercialmente: a variedade Pérola, conhecida também como Branco-de-Pernambuco, ou simplesmente Pernambucano; Amarelo comum ou Boituva;

e a variedade Smooth Cayenne, conhecido como Havaiano, ou simplesmente Havaí (MEDINA et al., 1978). 
Tabela 1. Composição química do abacaxi da variedade Smooth Cayenne.

\begin{tabular}{ccc}
\hline COMPOSIÇÃO & FRUTA VERDE & FRUTA MADURA \\
\hline $\mathrm{pH}$ & 3,2 & 3,7 \\
$\begin{array}{c}\text { Sólidos solúveis } \\
\left({ }^{\circ} \text { Brix }\right)\end{array}$ & 11,6 & 18,2 \\
$\begin{array}{c}\text { Acidez total } \\
(\% \text { ácido cítrico })\end{array}$ & 0,96 & 0,47 \\
$\begin{array}{c}\text { Açúcares totais } \\
(\% \text { base úmida })\end{array}$ & 9,85 & 16,17 \\
$\begin{array}{c}\text { Ácido ascórbico } \\
(\mathrm{mg} / 100 \text { g totais })\end{array}$ & 17 & 10 \\
\hline
\end{tabular}

Fonte: MEDINA et al., 1978.

A participação do Brasil no mercado externo de abacaxi é pequena, apesar de ser um fruto típico das regiões tropicais e subtropicais, e de o País sustentar a segunda maior produção mundial, sendo responsável pela produção de 2.491 .974 toneladas de abacaxi em 2008 (FAO, 2009). As principais plantações brasileiras estão concentradas respectivamente por ordem de produção nos estados da Pará, Paraíba, Minas Gerais, Bahia e Rio Grande do Norte (MINISTÉRIO DA AGRICULTURA, PECUÁRIA E ABASTECIMENTO, 2005), entretanto o estado de São Paulo também produz grande quantidade de abacaxis.

A sazonalidade da produção, por si só, justifica a necessidade de se industrializar parte da colheita, principalmente a produção excedente - uma maneira de evitar desperdícios e obter produto de maior valor agregado. Como o abacaxi é uma fruta temporária, a colheita das frutas, de modo geral, está intimamente relacionada á época de plantio, ao tipo e idade da muda. Mas a época de maior produção e, conseqüentemente, a época favorável à obtenção de mudas, é a que se estende de dezembro a fevereiro (MEDINA et al., 1978). 


\subsection{Produtos desidratados}

A desidratação ou secagem é uma forma conveniente de conservação de frutas e hortaliças, tornando-os disponíveis em todas as estações do ano. Os custos de processamento, embalagem, transporte e armazenamento são menores para os produtos desidratados quando comparados aos produtos enlatados ou congelados, ou até mesmo em sua forma in natura.

Pela redução do conteúdo de umidade de um alimento até níveis bem baixos, a chance de deterioração microbiológica é drasticamente diminuída e as taxas de outras reações de degradação são reduzidas significativamente. Além de favorecer a preservação, a desidratação reduz o peso e o volume do produto, reduzindo os custos do transporte e do armazenamento. Frequentemente, a desidratação de um produto alimentício resulta em um produto mais conveniente para o consumo do que o mesmo in natura.

O interesse pela desidratação tem aumentado em países desenvolvidos, onde as indústrias são motivadas pelo desenvolvimento de novos métodos de secagem de frutas e hortaliças que resultem em produtos com características especiais, de reconstituição instantânea, muito valorizados em alimentos de preparo rápido. Nesses países e, mesmo nas grandes cidades e regiões mais desenvolvidas do terceiro mundo, a mudança no estilo de vida

da população causou o aumento da demanda por uma grande variedade de frutas e hortaliças desidratadas que ofereçam conveniência, alta qualidade nutricional e características semelhantes às do produto fresco, implicando na necessidade de pesquisa básica sobre a influência das condições de secagem na qualidade do alimento (JAYARAMAN; DAS GUPTA, 1995).

Um potencial mercado consumidor tem apresentado crescimento considerável, como indústrias de produtos desidratados para fabricantes de misturas de cereais matinais e barras de cereais com pedaços de frutas, além de lojas de produtos naturais que comercializam frutas 
desidratadas para consumo direto ou para o preparo de chás (RODRIGUES, 2003). Os frutos secos apresentam a conveniência de produtos prontos para consumo, porém mantêm o apelo de alimento saudável, o que contribui para o aumento de seu valor agregado.

A técnica mais utilizada na produção de frutas e hortaliças desidratadas é a secagem por ar quente - onde o material a ser seco, usualmente na forma de pequenos pedaços ou fatias, é submetida a uma corrente de ar quente paralela ou perpendicular ao leito de sólidos (NIJHUIS et al., 1996). No entanto, segundo Singh e Heldman (1998), a preservação de frutas e hortaliças por desidratação apresenta um desafio: devido à configuração estrutural destes produtos, a remoção de umidade deve ser realizada de maneira a preservar ao máximo sua qualidade. Isto requer um processo que forneça um produto seco que possa retornar aproximadamente às suas condições originais após a reidratação. Para se conseguir a remoção de água de um produto alimentício da maneira mais eficiente, o sistema de desidratação deve levar em conta os vários processos e mecanismos de transformação que ocorrem no produto, que são de particular importância para frutas e vegetais, onde a própria estrutura influencia o movimento da água no interior do produto.

A secagem por ar quente normalmente ocasiona uma considerável queda na qualidade. Os defeitos mais comuns dos produtos desidratados estão relacionados às alterações estruturais provocadas pelo encolhimento dos produtos durante a secagem, o que leva à dureza excessiva, dificuldade de reidratação e alterações indesejáveis de cor e sabor.

É fato conhecido que a textura, a densidade, a facilidade de reidratação, a aglomeração e as propriedades mecânicas de alimentos desidratados dependem das propriedades e características da matéria-prima, da temperatura e umidade do ar de secagem, da configuração do secador e do tempo de residência do produto. De acordo com Jayaraman e Das Gupta (1995), a melhoria das características de reidratação e a manutenção da qualidade de alimentos secos por ar quente através da alteração das variáveis de processo, de modo a 
melhorar a transferência de calor e diminuir a temperatura, vem sendo objeto de um número cada vez maior de estudos. Por outro lado, a relação entre a qualidade do produto desidratado e as condições de secagem não são suficientemente exploradas na literatura devido à limitada compreensão dos mecanismos físico-químicos que afetam a qualidade do produto e do efeito destes mecanismos sobre as propriedades de transporte.

Strumillo e Adamiec (1996) apresentam uma tabela indicando as principais alterações na qualidade de alimentos durante a secagem (Tabela 2). As alterações bioquímicas, características das leveduras, bactérias e fungos, estão estreitamente conectadas com a perda de água nas células e nos seus elementos estruturais individuais. Alterações enzimáticas incluem principalmente as mudanças da atividade causada pela decomposição estrutural dos biopolímeros. Normalmente, as alterações químicas resultam no decréscimo do valor nutritivo do produto ou na formação de substâncias nocivas para o meio. As alterações bioquímicas e químicas manifestam-se muitas vezes como mudanças físicas: perda de solubilidade ou da capacidade de ligar-se à água e perda de componentes aromáticos devido à decomposição ou à alta volatilidade, além do escurecimento do produto.

Tabela 2. Alterações da qualidade de produtos alimentícios durante a secagem.

\section{$\begin{array}{lll}\text { FÍSICA } & \text { QUÍMICA } & \text { BIOQUÍMICA }\end{array}$}

- Encolhimento

- Perda de elasticidade

- Alteração na forma e tamanho (fraturas, enrugamento, poros)

- Cristalização ou mudança na estrutura cristalina

- Perda de solubilidade

- Reidratação limitada

- Perda de aromas
- Diminuição e perda de - Decomposição de atividade de reagentes

- Quebra de componentes químicos microrganismos e biomoléculas

- Oxidação de lipídeos

- Desnaturação de proteínas

- Escurecimento enzimático

- Reação de Maillard

- Oxidação ou inativação de vitaminas

Fonte: STRUMILLO; ADAMIEC, 1996. 
Nicoleti (2001) verificou que existe uma interação entre os efeitos da temperatura e da velocidade do ar de secagem sobre o encolhimento de fatias de abacaxi desidratado. Para maiores velocidades o encolhimento foi independente da temperatura, enquanto para velocidades mais baixas o encolhimento foi mais intenso à medida que a temperatura de secagem diminuiu. Esses efeitos são compatíveis com a teoria da transição vítrea (BHANDARI; HOWES, 1999), considerando-se que a secagem a temperaturas mais baixas expõe o material a temperaturas maiores que a ambiente por um período mais prolongado. $\mathrm{O}$ resultado seria que a matriz, com viscosidade mais baixa devido ao estado borrachoso (acima da temperatura de transição vítrea, $\mathrm{T}_{\mathrm{g}}$ ), teria mais tempo para se deformar. Isso acontece principalmente quando a velocidade do ar é baixa, reduzindo a difusividade efetiva e prolongando ainda mais o tempo de secagem. Em temperaturas mais altas, ou em maiores velocidades do ar, devido às altas taxas de secagem, a superfície da amostra se desidrata muito rapidamente, passando ao estado vítreo, que é caracterizado por uma estrutura mais rígida. Isso diminui a intensidade das deformações sofridas pela material. Por outro lado, Gabas, Menegalli e Telis-Romero (1999) observaram que, na desidratação de uvas, o encolhimento aumentou com o aumento da temperatura de secagem na faixa de 40 a $80^{\circ} \mathrm{C}$, enquanto o aumento da concentração de oleato de etila no pré-tratamento químico teve efeito contrário. Os mesmos autores (Gabas et al., 2002) verificaram que, na desidratação de ameixas, a temperatura teve pouca influência sobre o encolhimento.

Entre as técnicas de secagem disponíveis tem havido um interesse crescente na liofilização, a qual fornece produtos secos de estrutura porosa e com propriedades vantajosas de qualidade, as quais são ponderadas contra os custos elevados do processo.

A liofilização é considerada como o processo referência para a produção de produtos desidratados de alta qualidade. Em comparação com as técnicas clássicas de desidratação, as suas principais vantagens são a preservação da maior parte das propriedades originais do 
produto e sua alta capacidade de reidratação. O congelamento inicial do produto, que faz com que a água permaneça no estado sólido durante a liofilização, protege e enrijece a estrutura da matriz sólida e minimiza as alterações na forma do produto, com retração mínima, prevenindo a subseqüente migração da água líquida e dos solutos durante a etapa de sublimação. As baixas temperaturas empregadas no processo contribuem para preservar os componentes, como vitaminas e sais minerais, bem como para manter o sabor original e aroma. Além disso, a formação dos cristais de gelo, seguida pela sua sublimação, resulta em uma matriz homogênea e porosa (MARQUES; PRADO; FREIRE, 2009; HAMMAMI; RENÉ, 1997).

\subsection{Fundamentos da secagem}

Segundo Mc Cormick (1983), a secagem é normalmente considerada um processo de remoção de umidade de um sólido por evaporação. Quando o calor necessário para evaporar a água é fornecido ao material, ocorrem transferências simultâneas de calor e massa. A exposição de uma amostra úmida ao ar aquecido e com baixa umidade relativa provocará a transferência de calor e de massa simultaneamente, sendo o calor suprido pelo ar, que arrasta a umidade evaporada.

Durante a secagem, é na superfície do material que ocorre a evaporação da água, a qual foi transportada do interior do sólido. Os mecanismos mais importantes desse transporte são: difusão líquida, difusão de vapor e fluxo de líquido e de vapor. O conhecimento do conteúdo inicial e final (equilíbrio) de umidade do material, da relação da água com a estrutura sólida e do transporte da água do interior do material até a sua superfície possibilitam fundamentar o fenômeno da secagem. O fenômeno da secagem para materiais biológicos não pode ser generalizado, pois estes possuem características próprias e propriedades que podem sofrer importantes alterações durante a secagem. 
As características específicas de cada produto, associadas às propriedades do ar de secagem e ao meio de transferência de calor adotado, determinam diversas condições de secagem. Entretanto, a transferência de calor e de massa entre o ar de secagem e o produto é fenômeno comum a qualquer condição de secagem. Com base nos fenômenos de transferência de calor e de massa, o processo de secagem pode ser dividido em três períodos, representados esquematicamente na Figura 1.

A curva (a) é a curva de secagem e representa a diminuição do teor de água do produto durante a secagem, dado pelo conteúdo de umidade do produto em base seca $(X)$, em relação à evolução do tempo de secagem $(t)$. Esta curva pode ser obtida por pesagens sucessivas do produto durante a secagem em uma determinada condição de secagem. A curva (b) representa a velocidade (taxa) de secagem do produto, isto é, a variação do conteúdo de umidade do produto por unidade de tempo $(d X / d t)$ em relação à evolução do tempo, isto é, é a curva obtida pela diferenciação da curva (a).

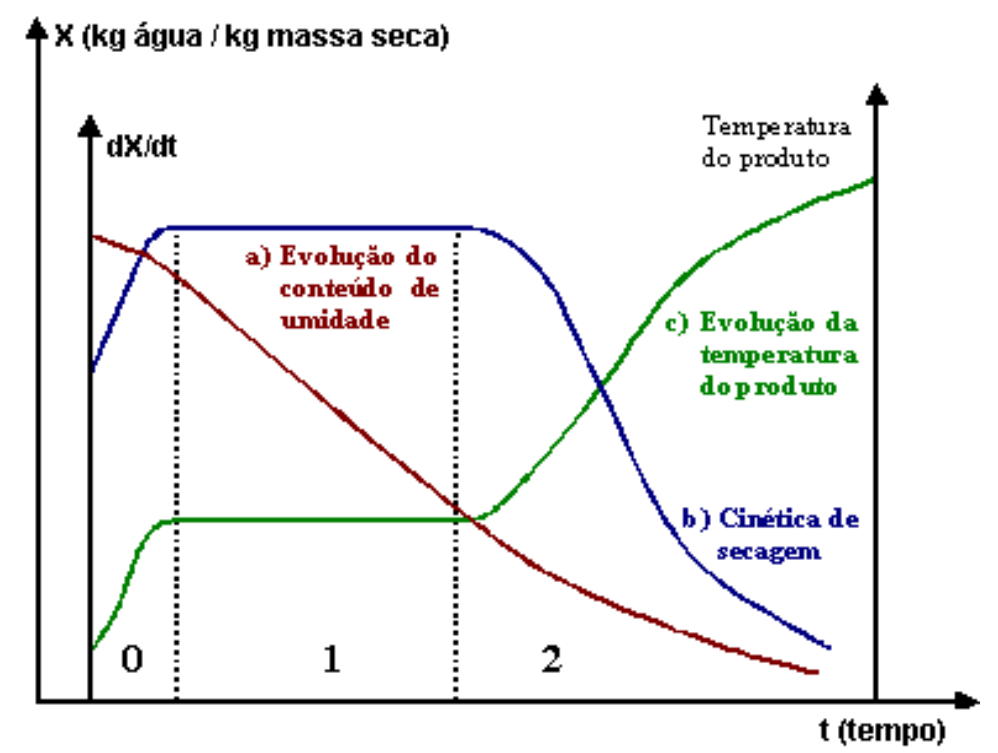

Fonte: PARK; YADO; BROD, 2001.

Figura 1. Curvas típicas de evolução da temperatura e da umidade do produto durante a secagem. 
A curva (c) representa a variação da temperatura do produto $(T)$ durante o tempo de secagem, isto é, a curva obtida pela medição da temperatura do produto durante o processo.

Cada uma dessas curvas pode ser dividida em três períodos característicos de acordo com o seu comportamento em função do tempo. O primeiro período (0) representa o início da secagem. Nesse período ocorre uma elevação gradual da temperatura do produto e da pressão de vapor de água. Essas elevações prosseguem até o ponto em que a taxa de transferência de calor do ar para o produto seja equivalente à taxa de transferência de massa, isto é de água do produto para a fase gasosa.

O segundo período (1) caracteriza-se pela taxa constante de secagem. A água evaporada é a água livre. As taxas de transferência de massa e de calor são equivalentes e, portanto, a velocidade de secagem é constante. Enquanto houver uma quantidade de água na superfície do produto suficiente para manter a evaporação, a taxa de secagem será constante. Um produto apresenta o período de taxa constante quando há um filme de água livremente disponível na superfície de secagem, num fenômeno similar à evaporação da água de um reservatório, com a temperatura do produto permanecendo igual à temperatura de bulbo úmido do ar de secagem (HAWLADER et al., 1991).

No terceiro período (2), a taxa de secagem é decrescente. A quantidade de água presente na superfície do produto é menor, reduzindo-se, portanto, a taxa de transferência de massa. A transferência de calor não é compensada pela transferência de massa; o fator limitante nessa fase é a redução da velocidade de migração da água do interior para a superfície do produto. A temperatura do produto aumenta, atingindo a temperatura de bulbo seco do ar de secagem.

Quando o produto atinge a umidade de equilíbrio em relação ao ar de secagem, o processo é encerrado. As regiões de taxa decrescente são indicativas de um aumento da resistência tanto para a transferência de calor quanto de massa, ocorrendo quando a superfície 
do alimento já não está totalmente molhada, tendo a umidade que percorrer o sólido até chegar à corrente de ar. Em alguns casos, podem ser observadas descontinuidades na curva de secagem, pois mudanças na estrutura do produto - endurecimento e/ou encolhimento poderão interferir na evolução do processo (HAWLADER et al., 1991).

Na desidratação de frutas e hortaliças, o período de taxa decrescente é especialmente importante. Nessa fase as partes externas do material já estão secas, enquanto o interior ainda pode conter quantidades significativas de umidade. A partir desse ponto, o processo consome grandes quantidades de energia e os atributos físicos, sensoriais e nutricionais do produto podem ser prejudicados devido à elevação da temperatura (NIJHUIS et al., 1996). Este período é quase sempre o único observado para a secagem de produtos agrícolas e alimentícios. A complexidade dos fenômenos que ocorrem durante a secagem conduz os pesquisadores a proporem numerosas teorias e múltiplas fórmulas empíricas para predizer a taxa de secagem: teoria difusional; teoria capilar; teoria de Luikov; teoria de Philip \& de Vries; teoria de Krisher - Berger \& Pei; teoria da condensação - evaporação (PARK; YADO; BROD, 2001). No estudo da secagem, após a obtenção das curvas e da caracterização dos períodos de secagem, é interessante descrever o processo matematicamente, de forma que as equações obtidas possam ser utilizadas no próprio estudo da cinética de secagem ou em projetos de secadores. As duas primeiras teorias citadas acima são básicas e fundamentam as demais teorias. A partir da aplicação dessas teorias a dados obtidos experimentalmente, podem-se calcular os coeficientes de transferência resultantes.

A teoria difusional se apóia exclusivamente sobre a lei de Fick, a qual expressa que o fluxo de massa por unidade de área é proporcional ao gradiente de concentração de água. Para analisar a secagem de alimentos e de produtos agrícolas, muitos autores têm utilizado a segunda lei de Fick para estimar o tempo médio de secagem durante o período de taxa 
decrescente. O modelo de Fick, dado pela Equação (1), representa a teoria da difusão da umidade como líquido ou vapor (RIZVI, 1995):

$$
\frac{\partial X}{\partial t}=\nabla\left(D_{e f} \nabla X\right)
$$

onde $X$ é a umidade em base seca; $t$ é o tempo de secagem e $D_{e f}$ é a difusividade efetiva da água.

Como o fenômeno de migração é complexo, trabalha-se com a difusividade efetiva, que engloba todos os efeitos que podem intervir nesse fenômeno. As soluções analíticas para a segunda lei de Fick aplicam-se a sólidos de formas geométricas simples e constantes ao longo do processo. Considerando-se que o sólido seja uma placa plana com ambas as superfícies expostas ao ar de secagem, de difusividade constante, variação do volume desprezível e que o efeito do gradiente de temperatura no interior da amostra também seja desprezível, tem-se a seguinte solução analítica (CRANK, 1975; HAWLADER et al., 1991):

$$
M=\frac{\left(X-X_{e q}\right)}{\left(X_{0}-X_{e q}\right)}=\frac{8}{\pi^{2}} \sum_{n=1}^{\infty} \frac{1}{(2 n-1)^{2}} \exp \left[-(2 n-1)^{2} \frac{\pi^{2} D_{e f} t}{L^{2}}\right]
$$

onde $M$ é a umidade adimensional, dada por $\left(X-X_{e q}\right) /\left(X_{0}-X_{e q}\right), X_{e q}$ é a umidade de equilíbrio em base seca, $X_{0}$ é a umidade inicial em base seca e $L$ é a espessura da placa.

A maioria dos cereais (arroz, trigo, feijão, soja, etc.) apresentam uma pequena mudança de volume durante a secagem. Desta maneira, a solução analítica pode ser aplicada satisfatoriamente no estudo destes materiais. Para alimentos de alto conteúdo de umidade como a maioria das frutas (uva, caqui, abacaxi, maçã, etc.) a variação de volume é grande e, por esta razão, as soluções analíticas não podem ser aplicadas de forma exata e devem ser consideradas como aproximações da solução real.

Diversos autores, como Nicoleti, Telis-Romero e Telis (2001), que estudaram a secagem de fatias de abacaxi fresco e com pré-tratamento osmótico, e Hawlader et al. (1991), 
que investigaram a secagem de tomates, utilizaram a segunda lei de Fick na modelagem dos dados experimentais, obtendo bons resultados.

\subsection{Liofilização}

A liofilização é um processo de desidratação baseado na sublimação da água presente no produto. Para isso, o material a ser seco é previamente congelado e, em seguida, submetido a um aquecimento controlado sob pressão reduzida. Pelo fato do processo ser realizado a baixa temperatura e em ausência de ar atmosférico, praticamente não se alteram as propriedades químicas e organolépticas do produto. Comparando-se o processo de liofilização com outros processos de secagem, isto é, a secagem a altas temperaturas, à pressão ambiente e sem congelamento prévio, verifica-se que ele apresenta as seguintes vantagens: menor contração do produto; maior solubilidade devido à estrutura esponjosa deixada pela saída de água; evita decomposição pelo calor; reduz a perda de voláteis sem afetar a qualidade do produto; reduz as ações enzimáticas (químicas) dos microrganismos; evita também a desnaturação de proteínas, além de manter a morfologia inicial do material (ORREGOALZATE, 2008).

O diagrama de fases da água, mostrado a seguir, permite avaliar o estado físico de uma amostra de água em função da pressão e da temperatura em que está submetida. Dessa forma, é possível observar que, para que ocorra a sublimação, a pressão e a temperatura deverão permanecer em valores inferiores aos correspondentes ao ponto triplo ou tríplice da água. 


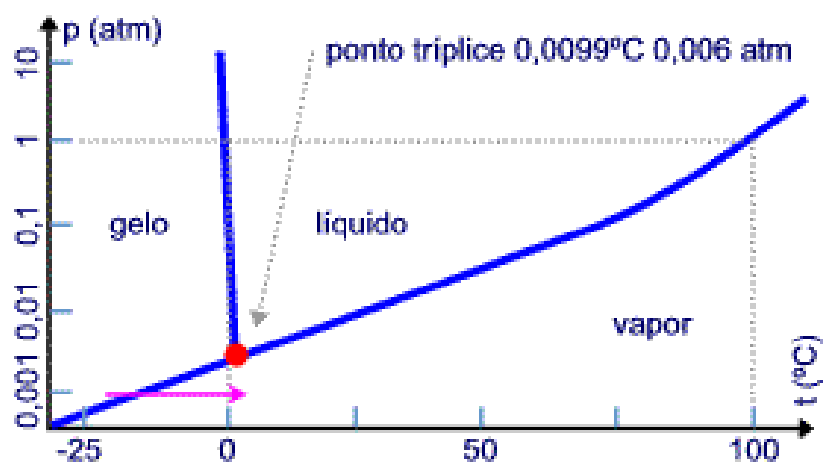

Fonte: MPSC INFORMAÇÕES TÉCNICAS (2010)

Figura 2. Diagrama de fases da água pura.

Um fator proeminente é a estrutura rígida da substância obtida pelo congelamento, que previne o colapso da matriz sólida, resultando em uma estrutura porosa que facilita a reidratação da mesma. No entanto, trata-se de um processo caro, que apresenta uma taxa de secagem relativamente baixa. Além disso, a utilização de energia para a sublimação e para a remoção do vapor de água da câmara constitui um fator de alto custo (KOROISHI, 2005).

Uma das maiores limitações da liofilização é a sua longa duração. As causas desse problema são o baixo desempenho de transferência de calor no interior do produto e as baixas pressões de trabalho, que fazem com que o principal mecanismo de transferência de calor seja a radiação, uma vez que existe pouca convecção e uma baixa condução entre as superfícies de contato sob vácuo (HAMMAMI; RENÉ, 1997).

O mecanismo da liofilização, isto é, o congelamento seguido de secagem por sublimação, induz à obtenção de produtos que em sua maioria estão no estado amorfo, ou seja, estão sujeitos a alterações em sua microestrutura. Devido à natureza amorfa dos biopolímeros, as formulações liofilizadas exibem freqüentemente o fenômeno da transição vítrea, um importante fator para a evolução do ciclo de liofilização. A temperatura de transição vítrea de um produto a ser liofilizado pode ser avaliada e utilizada para a 
determinação das condições de processo que otimizem a qualidade e a estabilidade do mesmo (CHEN; OAKLEY, 1995).

Um sistema de liofilização é constituído basicamente de uma câmara a vácuo, um condensador, um compressor e a bomba de vácuo, como ilustrado na Figura 3. O congelamento inicial do material geralmente é conduzido de forma independente do liofilizador propriamente dito, sendo o material já congelado introduzido diretamente na câmara de vácuo.

Três estágios distintos caracterizam o processo de liofilização: o estágio de congelamento, o estágio de secagem primária e o estágio de secagem secundária. Um típico perfil de temperatura ao longo do tempo de processo abrangendo esses três estágios é ilustrado na Figura 4.

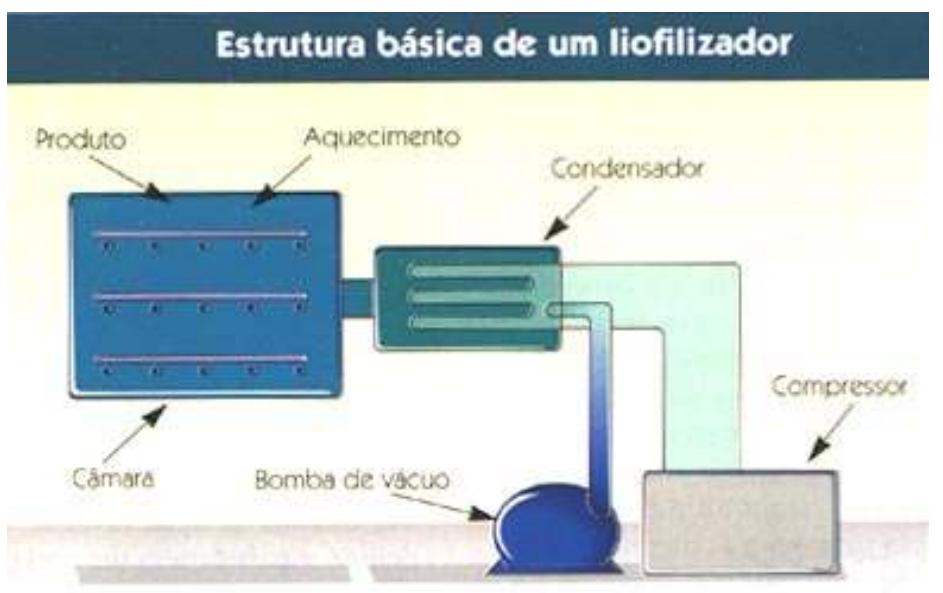

Fonte: VITAL; LUZ; LIMA, 2003.

Figura 3. Estrutura básica de um liofilizador. 


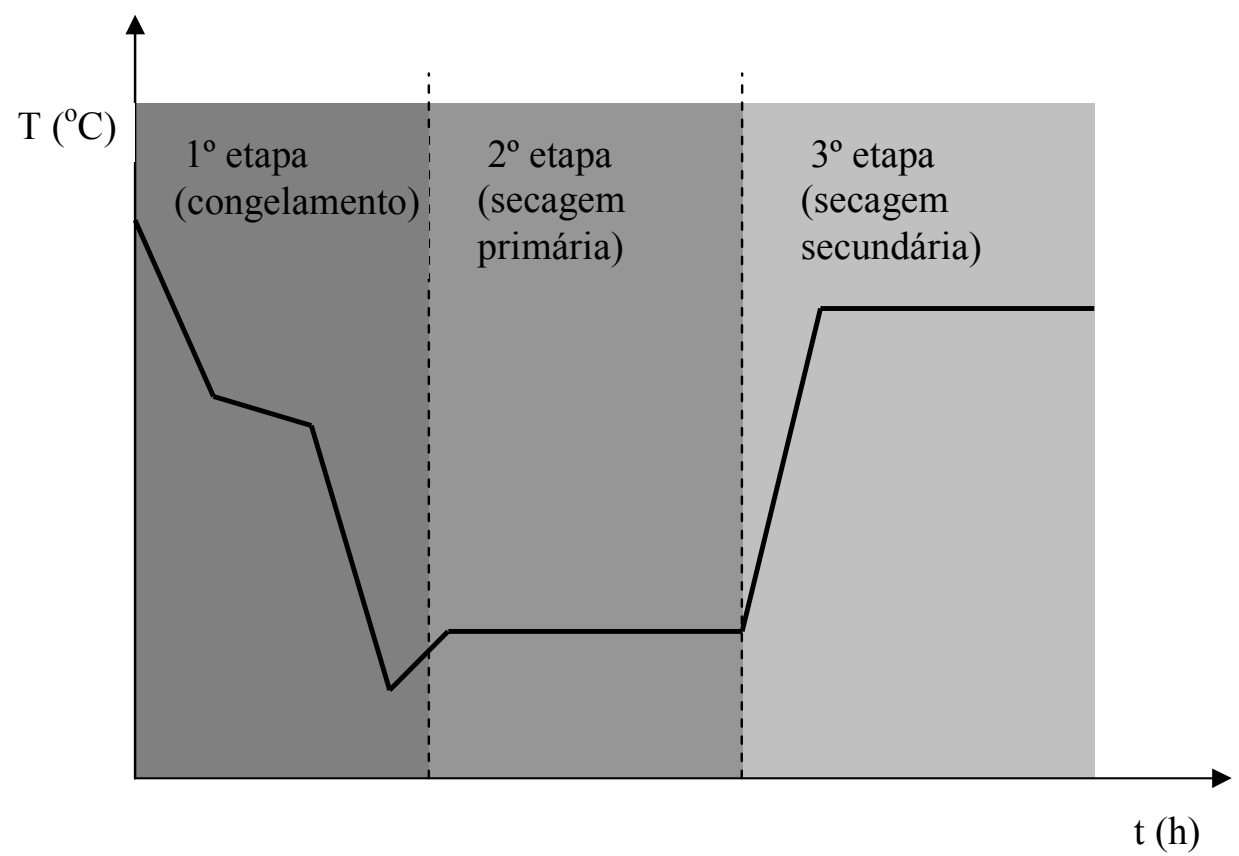

Figura 4. Estágios do processo de liofilização.

No estágio de congelamento, o material torna-se completamente sólido a temperaturas inferiores ao seu ponto de início de congelamento. O uso do congelamento para a preservação de alimentos data de tempos pré-históricos. Os homens primitivos observaram que em temperaturas climáticas baixas os alimentos perecíveis podiam ser mantidos quase indefinidamente e com a mesma qualidade durante o tempo em que permaneciam congelados. O uso de baixas temperaturas pode controlar a taxa de reações químicas, ou seja, a velocidade na qual moléculas podem mover-se, determinando a velocidade com que reagem com outras moléculas. O principal fator de estudo do congelamento é como a velocidade de congelamento influencia nas características do produto final (COLLA, HERNÁNDEZ; 2003).

No estágio de secagem primária a água congelada é removida por sublimação originando espaços vazios no interior da matriz alimentícia que antes eram ocupados pelo gelo sublimado, tornando desta forma, o alimento poroso. Nessa etapa, a maior parte da água 
é removida, em torno de $90 \%$ do conteúdo original. Entretanto, ainda podem restar quantidades significativas de água ligada no interior do produto, necessitando de um potencial adicional. A força motriz desta etapa é o aquecimento realizado no estágio de secagem secundária, em que ocorre a dessorcão da água ligada, com a umidade final podendo chegar até $2 \%$. É nessa etapa onde há maior possibilidade de ocorrer o colapso estrutural do produto, caso a temperatura atinja valores excessivos (SNOWMAN, 1997).

Os três estágios fundamentais do processo serão detalhados a seguir.

\subsubsection{Estágio de congelamento}

Os principais processos de congelamento de alimentos utilizados industrialmente são: congelamento com ar sujeito apenas à convecção natural, congelamento em placas, congelamento com circulação forçada de ar, congelamento por imersão ou aspersão de líquidos e congelamento criogênico.

O congelamento envolve a redução da temperatura até temperaturas abaixo do ponto de congelamento, causando a cristalização da maior parte da água presente no produto e, eventualmente dos solutos presentes. Esses efeitos não ocorrem individualmente, mas simultaneamente, compreendendo a redução da temperatura sem mudança de fase e a cristalização (COLLA, HERNÁNDEZ; 2003).

Antes do congelamento, o calor sensível é removido, diminuindo a temperatura do alimento até a sua temperatura inicial de congelamento, o qual se situa abaixo do ponto de congelamento da água pura devido às substâncias dissolvidas nas soluções que formam o alimento. Essa etapa consiste na redução da temperatura abaixo do ponto de congelamento sem que ocorra a mudança de fase. Os principais efeitos ocasionados pela redução rápida da 
temperatura sem mudanças de fase são: a injúria celular, no caso de tecidos como frutas e vegetais, e o choque térmico em microrganismos.

Em seguida, ocorre o congelamento propriamente dito, isto é, a retirada de calor latente do produto, promovendo a formação de gelo. Esse pode ser considerado o primeiro estágio do processo de liofilização, sendo que o desempenho global da liofilização depende significativamente deste estágio.

Uma vez que as mudanças de fase sólido-líquido são as responsáveis pela maior parte das causas de letalidade de microrganismos e da perda de qualidade de tecidos vivos sob congelamento, a compreensão da cristalização é essencial para a melhor utilização dos métodos de conservação por congelamento. A formação e distribuição de tamanho dos poros, e a conectividade da rede de poros da camada seca formada durante o estágio de secagem primária dependem do tamanho e da homogeneidade dos cristais de gelo formados durante estágio de congelamento.

A diferença entre os métodos de congelamento utilizados é a velocidade em que ocorre o congelamento, o modo como o resfriamento é produzido e como a energia é transferida para o produto congelado. A etapa de congelamento geralmente é realizada por transferência de calor por meio de convecção (corrente de ar) e/ou condução (através de uma superfície de contato). A escolha do tipo de congelamento depende das características do produto (KOROISHI, 2005).

De acordo com Nakagawa, Hottot e Andrieu (2007), a otimização do processo de congelamento tem uma importância crítica para a liofilização, uma vez que a subseqüente taxa de sublimação do gelo é fortemente relacionada à morfologia dos cristais de gelo, bem como a maioria dos parâmetros de textura e de estrutura do produto são estabelecidos durante a etapa de congelamento. Assim, no que se refere à otimização da etapa de congelamento, o maior desafio é o controle da morfologia dos cristais de gelo, incluindo seu tamanho médio, 
distribuição de tamanho e forma. Kochs et al. (1993) concluíram que a redução da taxa de congelamento levou a um aumento significativo das taxas de transferência de massa durante a sublimação, consequentemente reduzindo o tempo necessário para liofilização.

Por outro lado, o congelamento lento é prejudicial para células, pois propicia a formação de grandes cristais de gelo que, após a sublimação da água ou da substância aquosa podem causar prejuízos mecânicos à estrutura das células. No entanto o congelamento rápido é resultado de uma queda brusca de pressão ou temperatura e, em resposta a esta espécie de choque, pequenos cristais de gelo são formados e distribuídos uniformemente sem afetar a estrutura da célula.

A localização dos cristais de gelo nos tecidos e suspensões celulares é função da taxa de congelamento, da temperatura e da natureza das células. O congelamento lento (taxa de $1 \%$ min) de tecidos vegetais, animais ou suspensões celulares geralmente causa a formação de cristais de gelo, principalmente no meio extracelular. Condições que levam preferencialmente à formação de cristais no meio extracelular resultam em cristais maiores de gelo, associados ao máximo deslocamento de água e encolhimento das células no estado congelado.

Todos os tipos de tecidos, animais, vegetais ou células de microrganismos, sem exceção, exibem uma distribuição de cristais de gelo uniforme quando congelados rapidamente sob temperaturas muito baixas. Condições que produzem cristalização intracelular resultam em formação de pequenos cristais de gelo em grande quantidade, com mínimo deslocamento da água, sendo que a aparência do produto congelado é similar à do produto não-congelado, sendo o produto obtido de melhor qualidade que aquele produzido sob baixas taxas de congelamento (BOSS, 2004). 


\subsubsection{Estágio de secagem primária}

No estágio de secagem primária a água congelada é removida por sublimação e, na medida em que o gelo sublima, formam-se poros no interior do produto que está sendo desidratado. Durante este estágio é removida a maior parte da umidade, a qual se transfere da fase sólida para a fase gasosa.

Desde que se disponha de um sistema eficiente de remoção do vapor de água da fase gasosa, o processo de sublimação continuará até que esgote o gelo presente. Essa função é desempenhada pelo condensador, elemento que deve oferecer uma superfície suficientemente fria para que o vapor de água passe novamente para a fase sólida. A força motriz que mantém a sublimação é o gradiente de pressão de vapor entre a superfície congelada do produto e a superfície do condensador.

O fornecimento do calor necessário para a sublimação pode ocorrer através de diferentes mecanismos de transferência de calor: radiação desde a placa aquecedora superior à bandeja onde está o produto; condução desde a superfície da placa inferior através da fina película de ar que se forma entre o recipiente do produto e a placa aquecedora; condução através da camada seca do material até a interface sólida (ORREGO-ALZATE, 2008).

A otimização do estágio de secagem primária reside em encontrar condições de operação que maximizem a quantidade de água removida. Neste estágio, a forma dos poros e a distribuição da temperatura na camada seca do produto não podem ser controladas. Quando ocorre fusão em algum ponto na camada congelada, o líquido (solvente) não pode ser removido por sublimação. Logo, o estágio de secagem primária sofre uma deficiência da secagem do material, uma redução na estabilidade estrutural do produto (BOSS, 2004). 


\subsubsection{Estágio de secagem secundária}

O estágio de secagem secundária inicia-se teoricamente quando todo o gelo foi removido por sublimação. Nessa etapa as porções remanescentes de água não congelada, que não sublimam na primeira etapa da secagem, são removidas por evaporação devido ao aumento de temperatura que ocorre no produto.

As partes secas do material podem iniciar sua secagem secundária mesmo que ainda haja presença de gelo sendo sublimado em outras partes do mesmo. Enquanto estes dois fenômenos coexistirem, devido ao gelo que sublima e causa o resfriamento do material, a temperatura do mesmo permanece controlada. Por outro lado, quando desaparece a última porção de gelo, ocorre o aumento da temperatura. Nesse caso, é preciso ter cuidado com materiais no estado amorfo, pois se sua temperatura de transição vítrea for superada, pode ocorrer o colapso do material. Como essa temperatura aumenta à medida que diminui a umidade do produto, é recomendável que durante a secagem secundária a temperatura seja aumentada de forma gradual (ORREGO-ALZATE, 2008).

O objetivo deste estágio é encontrar as condições de operação que minimizem a duração do processo sem perder em termos de estabilidade do produto, proporcionando no final deste estágio uma concentração de umidade desejável, na qual não se tenham problemas com armazenagem.

\subsection{Atributos de Qualidade}

\subsubsection{Vitamina $C$}


A idéia de que determinados compostos orgânicos presentes em alimentos em quantidades mínimas eram essenciais nutricionalmente, ou seja, a idéia da existência das "vitaminas" surgiu a partir dos resultados de estudos em duas áreas de pesquisa: a de necessidades nutricionais e a de patologia de doenças como o escorbuto (doença causada pela falta de vitamina $\mathrm{C}$, caracterizada por enfraquecimento geral, hemorragias diversas; mau hálito e sangria das gengivas) e beribéri (doença causada pela falta de vitamina B1), que depois foram classificadas como doenças de deficiência nutricional.

As vitaminas são substâncias orgânicas que atuam em quantidades mínimas em diversos processos metabólicos. A maioria das vitaminas não pode ser fabricada pelo corpo, por isso é necessário obtê-las a partir dos alimentos (STADLER,1999).

A vitamina $\mathrm{C}$ tem sido, há muito tempo, motivo de grandes controvérsias. A recomendação diária de vitamina $\mathrm{C}$ é de apenas $60 \mathrm{mg} /$ dia. Muitos cientistas têm discordado desses valores, incluindo Linus Pauling, cientista laureado com dois Prêmios Nobel e que pessoalmente recomendava $3 \mathrm{~g} / \mathrm{dia}(3000 \mathrm{mg})$. É sabido que as $60 \mathrm{mg}$ são recomendadas para prevenção de escorbuto, mas não se sabe ainda o que seria a dosagem ideal, para a potencialização máxima da saúde. A vitamina $\mathrm{C}$ é um poderoso antioxidante porque impede a oxidação, isto é, a perda de elétrons (GUIMARÃES; KUWABARA, 2004).

A vitamina $\mathrm{C}$, conhecida como ácido ascórbico, está presente em frutas cítricas e seu conteúdo varia consideravelmente nessas frutas, em torno de $73,2 \mathrm{mg} / 100 \mathrm{~g}$ de material. Os níveis de vitamina $\mathrm{C}$ são influenciados por vários fatores: produção, condições climáticas, maturidade, tipo de fruta (espécie e variedade), manipulação e estocagem da fruta, e, principalmente, os parâmetros usados no processamento. A vitamina C é extremamente instável e perde suas propriedades na presença de ar, calor, água ou luz, o que dificulta sua permanência nos alimentos processados. Sendo assim, geralmente, a retenção de vitamina C é tomada como um índice de qualidade dos processamentos tecnológicos de alimentos, uma vez 
que, se houver um bom nível de retenção da mesma, pode-se deduzir que o processo apresentou pouca degradação dos demais nutrientes (FENNEMA, 1977).

O valor de referência do conteúdo de ácido ascórbico para o abacaxi in natura é de $16.9 \mathrm{mg}$ de Vitamina C/ 100g de polpa (US Department of Agriculture, 2008). A Tabela 1 mostra que esse conteúdo decresce com o amadurecimento da fruta.

Marques, Ferreira e Freire (2007) observaram que o estágio de maturação de acerolas afetou a retenção de vitamina $\mathrm{C}$ durante a liofilização. A menor perda desse nutriente $(13 \%)$ foi observada num estágio intermediário de maturação. Esses autores justificaram tais diferenças pela instabilidade e sensibilidade do ácido ascórbico ao conteúdo de umidade, $\mathrm{pH}$ e presença de íons metálicos, os quais variam ao longo do processo de maturação da fruta.

Stadler (1999) observou que, entre vários os sucos e alimentos testados, o suco concentrado de maracujá apresentou maior teor de vitamina $\mathrm{C}$ e, pelos demais resultados obtidos, observou uma diferença na quantidade de vitamina $\mathrm{C}$ no suco fresco e no suco preparado no dia anterior à análise, concluindo que sucos industrializados prontos para consumo são os que apresentaram os menores teores de vitamina C.

As moléculas do ácido ascórbico sofrem oxidação antes que outras moléculas se oxidem, impedindo e protegendo essas outras moléculas da oxidação. Segundo Aldrigue et al. (2002), o ácido ascórbico (vitamina C) tem função muito importante devido à sua ação fortemente redutora. É largamente empregado como agente antioxidante para estabilizar a cor e o aroma do alimento. Além do emprego como conservante, o ácido ascórbico é utilizado pelo enriquecimento de alimentos ou restauração, a níveis normais, do valor nutricional perdido durante o processamento (CHAVES et al., 2004).

Diversas investigações que levam em consideração a degradação de vitamina $\mathrm{C}$ em frutas submetidas aos processos de secagem podem ser encontradas na literatura. Nicoleti et al. (2007) na secagem de caquis, Madrau et al. (2009) para damascos, Marfil et al. (2008) para 
fatias de tomates, Queiroz et al. (2008) para goiabas, Wojdyło et al. (2009) para morangos entre outros.

Almeida et al. (2009) verificaram que os conteúdos de vitamina $C$ para as variedades de manga 'Tommy Atkins' e 'Rosa' liofilizadas, sofreram redução de 78,46 para 58,03 $\mathrm{mg} / 100 \mathrm{~g}$ e de 79,55 para $65,45 \mathrm{mg} / 100 \mathrm{~g}$, respectivamente, fato este que foi atribuído ao fato de a vitamina $\mathrm{C}$ ser sensível à exposição à luz.

\subsubsection{Reidratação}

A reidratação de um produto seco caracteriza a qualidade do produto final, e os índices de reidratação indicam os danos provocados pela secagem aos tecidos do alimento (GABAS et al., 1999). Pode ser expressa de várias maneiras e, freqüentemente, um mesmo índice recebe nomes diferentes, como por exemplo, relação de reidratação (KALRA et al., 1986), capacidade de reidratação (LEVI et al., 1988) ou coeficiente de hidratação (OGWAL; DAVIS, 1994). Uma forma comum de expressar o índice reidratação é através da seguinte expressão:

$$
\text { indice de reidratação }=\frac{\text { massa de amostra reidratada }}{\text { massa de amostra antes da reidratação }}
$$

Alves-Filho e Strommen (1996), ao estudarem a aplicação de bomba de calor associada à liofilização de materiais biológicos, reidrataram maçãs, morangos e peixes comparando o tempo de imersão do produto seco, temperatura da água de reidratação (10 e 99 $\left.{ }^{\circ} \mathrm{C}\right)$, temperatura do ar de secagem $\left(-5\right.$ a $40{ }^{\circ} \mathrm{C}$ para peixes e -25 a $35{ }^{\circ} \mathrm{C}$ para as frutas $)$, forma e tamanho das amostras. Obtiveram maior porcentagem de reidratação para maiores tempos de imersão e temperaturas de secagem mais baixas. Observaram ainda, que a taxa de reidratação dos peixes secos a $-5{ }^{\circ} \mathrm{C}$ aumentou quando a amostra foi reidratada em água a 10 ${ }^{\circ} \mathrm{C}$ e, para os peixes secos a temperatura maior $\left(30^{\circ} \mathrm{C}\right)$, a taxa se inverteu, e os maiores valores 
foram alcançados para a reidratação conduzida a $99{ }^{\circ} \mathrm{C}$. Marques, Prado e Freire (2009) reidrataram frutas liofilizadas, entre elas, abacaxi, acerola, manga, mamão e goiaba. De acordo com os resultados, apesar do abacaxi apresentar menor capacidade de reidratação absorver menores quantidades de água - a fruta atingiu o equilíbrio de reidratação, caracterizado pela não alteração de sua massa, em um tempo menor comparado as demais frutas, com exceção da manga.

Devido ao encolhimento e ao endurecimento (formação de crosta), a reidratação de produtos secos por ar quente tem menor eficiência (NIJHUIS et al., 1996). Pesquisadores tentam controlar este efeito adverso alterando as condições de processamento ou associando pré-tratamentos como branqueamento ou imersão do produto em soluções osmóticas antes da secagem (NICOLETI, 2001).

Hammami e René (1997) não observaram diferenças significativas no índice de reidratação de morangos liofilizados em diferentes condições de pressão e temperatura. No entanto esses autores citam diversos trabalhos em que se observou que o índice de reidratação é afetado principalmente pela taxa de congelamento do produto, sendo maior a reidratação de produtos congelados em maior temperatura.

\subsubsection{Textura}

Os testes reológicos são importantes na obtenção de parâmetros de projeto de equipamentos, na compreensão da estrutura de produtos alimentícios e como indicativo de sua qualidade (BAGLEY; CHRISTIANSON, 1987).

O primeiro texturômetro, denominado tenderômetro, foi construído pelo Laboratório de Tecnologia de Alimentos do Instituto de Tecnologia de Massachusetts. Este instrumento empregava um medidor de deformação conectado ao maxilar do articulador dental. Um 
importante passo para a avaliação da análise de textura em alimentos veio através da modificação do tenderômetro original. $\mathrm{O}$ analisador geral de textura dos alimentos foi desenhado para simular a ação da mastigação da boca humana, apresentando graficamente uma curva de forca em função do tempo, que se tornou conhecida como o perfil da textura (RAO; DELANY; SKINNER, 1994).

Nos últimos anos a importância da textura vem se revelando como um parâmetro essencial a ser considerado como atributo da qualidade devido aos hábitos alimentares dos consumidores que estão se tornando cada vez mais sofisticados. A correlação de textura instrumental com a sensorial tem sido buscada com o propósito de melhorar os produtos disponíveis, bem como no desenvolvimento de novos produtos e no controle de qualidade do processamento e manipulação dos alimentos. O teor de umidade remanescente é o principal fator que influencia na textura das frutas desidratadas, já que baixos teores de umidade tornam a textura da fruta dura, ao passo que níveis intermediários de umidade podem estar associados a uma fruta com textura agradável.

A Análise de Perfil de Textura (TPA), desenvolvida por um grupo de pesquisa da General Foods Corporation nos anos 60, vem sendo muito utilizada como forma de obtenção de alguns parâmetros de textura em alimentos. Este teste tem mostrado elevada correlação existente entre medições próprias comparadas com aquelas realizadas através de análise sensorial (MORGADO; ABREU, 2001).

O método TPA consiste da compressão da amostra em duas etapas, fornecendo um gráfico de força pelo tempo. Os parâmetros são calculados automaticamente através das relações entre as áreas dos picos do gráfico. Os atributos de qualidade que podem ser detectados em um teste de TPA são a fraturabilidade, dureza, coesividade, adesividade, elasticidade, pastosidade e mastigabilidade, os quais são relacionados à curva de força versus tempo, de acordo com a Figura 5. 
Com referência à Figura 5, os parâmetros de avaliação por TPA são definidos da seguinte forma (TELIS; TELIS-ROMERO; GABAS, 2005):

- Fraturabilidade $\left(\mathrm{F}_{1}\right)$ : força no ponto em que ocorre a primeira ruptura significativa na área positiva.

- Dureza $\left(\mathrm{F}_{2}\right)$ : força necessária para alcançar uma deformação pré-selecionada, sendo calculada como sendo o pico de máxima força aplicada no primeiro ciclo de compressão.

- Coesividade: razão entre as áreas $\mathrm{A}_{1: 3}$ e $\mathrm{A}_{4: 6}$.

- Adesividade: área negativa $\mathrm{A}_{3: 4}$, que representa o trabalho necessário para separar a sonda da superfície da amostra.

- Elasticidade: é a altura que a amostra recupera durante o tempo entre o final do primeiro ciclo de compressão e o início do segundo ciclo de compressão.

- Pastosidade: dada pelo produto entre os valores da dureza e da coesividade.

- Mastigabilidade: dada pelo produto entre os valores da pastosidade e da elasticidade.

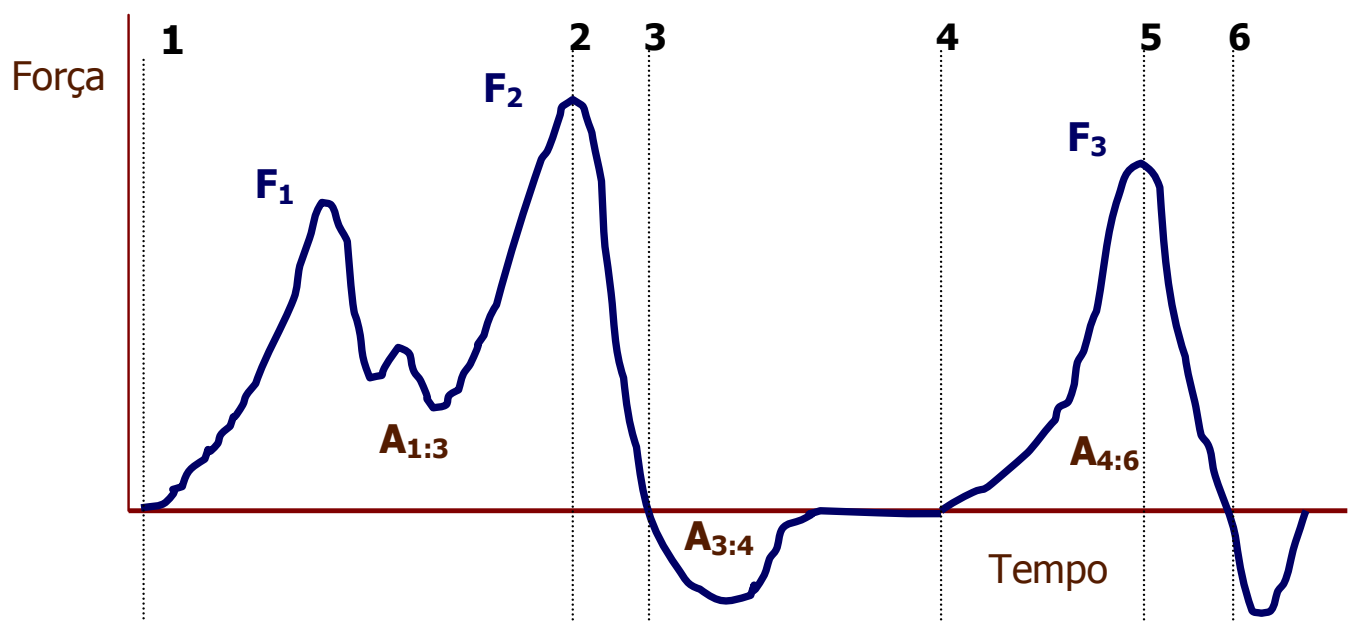

Fonte: TELIS; TELIS-ROMERO; GABAS, 2005.

Figura 5. Curva generalizada obtida através de um teste de TPA 
Diversos trabalhos têm sido desenvolvidos buscando compreender a influência das condições de secagem sobre a textura de frutas desidratadas. Nicoleti et al. (2005) avaliaram as propriedades reológicas em testes de compressão-relaxação em caquis secos. Boudhrioua et al. (2002) investigaram a firmeza de bananas durante a secagem e seu armazenamento. Gabas et al. (2002) obtiveram resultados correlacionados à textura para ameixas secas em função do conteúdo de umidade, enquanto Ferreira et al. (2008) aplicaram testes de TPA em pêras secas em secador solar. 


\section{MATERIAL E MÉTODOS}

\subsection{Matéria-prima}

Para os experimentos foram utilizados abacaxis do tipo Havaí (variedade Smooth Cayenne) adquiridos no mercado local (região de São José do Rio Preto, SP) algumas horas antes do processamento. A cada ensaio foram utilizados dois abacaxis de tamanho médio, maduros e sem injúrias nas cascas.

Os abacaxis foram descascados manualmente e, em seguida, fatiados transversalmente com auxílio de um fatiador mecânico nas espessuras de 0,5; 1,0 e 1,5 cm. Foram utilizadas somente as fatias da região central da fruta, de modo a garantir a uniformidade do diâmetro, sendo descartadas as extremidades.

Determinou-se o grau de maturação por leitura de ${ }^{\circ}$ Brix em refratômetro digital com compensação automática de temperatura (modelo PAL 3, marca Atago, Tokyo, Japan). A determinação da umidade inicial das amostras foi realizada pelo método gravimétrico em uma estufa a vácuo a $60{ }^{\circ} \mathrm{C}$ por $48 \mathrm{~h}$. As frutas utilizadas apresentaram teor de sólidos solúveis entre 10 e $19^{\circ}$ Brix e umidade entre 78 e $88 \%$ (b.u.).

\subsection{Congelamento}

Após o corte, as fatias da fruta fresca foram imediatamente levadas ao congelamento, sendo posicionadas horizontalmente sobre as prateleiras de um freezer vertical (modelo FV500, marca Liotop, São Carlos, Brasil). 
As temperaturas de congelamento e a espessura das fatias foram variadas de acordo com um planejamento experimental do tipo fatorial $3^{2}$, isto é, dois fatores ou variáveis independentes (espessura da fatia e temperatura de congelamento) com três níveis de variação $\left(0,5 ; 1,0\right.$ e $1,5 \mathrm{~cm} \mathrm{e}-14{ }^{\circ} \mathrm{C} .-24{ }^{\circ} \mathrm{C}$ e $\left.-34{ }^{\circ} \mathrm{C}\right)$, totalizando 9 ensaios, de acordo com a Tabela 3.

Tabela 3. Planejamento experimental para o congelamento das fatias de abacaxi.

\begin{tabular}{ccc}
\hline Ensaio & $\begin{array}{c}\text { Espessura da fatia } \\
(\mathbf{c m})\end{array}$ & $\begin{array}{c}\text { Temperatura de congelamento } \\
\left({ }^{\circ} \mathbf{C}\right)\end{array}$ \\
\hline 1 & 0,5 & -14 \\
2 & 1,0 & -14 \\
3 & 1,5 & -14 \\
\hline 4 & 0,5 & -24 \\
5 & 1,0 & -24 \\
6 & 1,5 & -24 \\
\hline 7 & 0,5 & -34 \\
8 & 1,0 & -34 \\
9 & 1,5 & -34 \\
\hline
\end{tabular}

No freezer, durante todo o congelamento, foi realizado o monitoramento de três temperaturas: temperatura do ar interno do freezer, próximo às amostras, temperatura da superfície da fatia e temperatura do centro da fatia. As tomadas de temperaturas foram feitas por um registrador FieldLogger (Novus, Porto Alegre, Brasil), com sensores de temperatura do tipo PT-100. Estas medições serviram como base para o cálculo da velocidade de congelamento. As amostras foram mantidas no freezer até que a temperatura de sua superfície entrasse em equilíbrio com a temperatura do centro da fatia, quando então eram conduzidas ao liofilizador. 


\subsection{Liofilização}

A liofilização das fatias de abacaxi foi conduzida em um liofilizador de bancada (modelo L-101, marca Liotop, São Carlos, Brasil), apresentado na Figura 6. Este equipamento consiste basicamente de uma câmara de secagem acrílica cilíndrica e transparente. Na parte superior da câmara há uma tampa em aço inox que acopla oito torneiras de silicone para o encaixe dos frascos de vidro com o sistema de alívio de vácuo. No interior da câmara de secagem há um suporte em aço inoxidável para quatro bandejas de inox. O liofilizador é acompanhado por uma bomba de vácuo com válvula eletromagnética que evita o refluxo de vapores, além de um dispositivo para a retirada de vapores d'água e filtro de exaustão de gases.

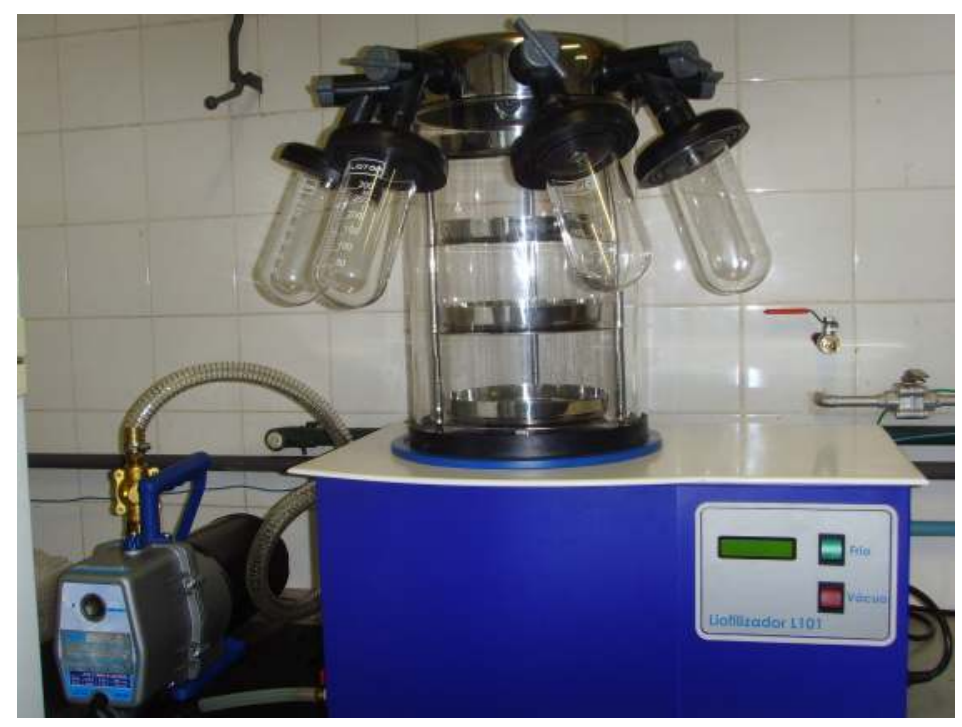

Figura 6. Liofilizador utilizado na realização dos ensaios de secagem.

Nos nove ensaios realizados, uma parte (aproximadamente $3 / 4$ ) do material foi desidratada no cilindro interno do liofilizador, com as amostras dispostas sobre as bandejas, como indicado na Figura 7. A liofilização foi conduzida a uma pressão abaixo de $500 \mu \mathrm{mHg}$ e 
a uma temperatura $-45^{\circ} \mathrm{C}$, ressaltando que, estes dois parâmetros não podem ser controlados pelo operador, pois o equipamento não possui este dispositivo. As amostras permaneceram no equipamento em operação por um período de 24 horas e em seguida, foram acondicionadas em dessecadores contendo solução salina saturada, de modo a fornecer ambientes com umidade relativa constante de 0,432. Após o condicionamento, essas amostras foram utilizadas para a realização das análises de textura e reidratação.

A outra parte do material (o $1 / 4$ restante) foi distribuída nos frascos laterais do liofilizador (Figura 6). A massa inicial de amostra inserida em cada um dos frascos foi registrada, uma vez que tais amostras foram utilizadas para a determinação da cinética de secagem.
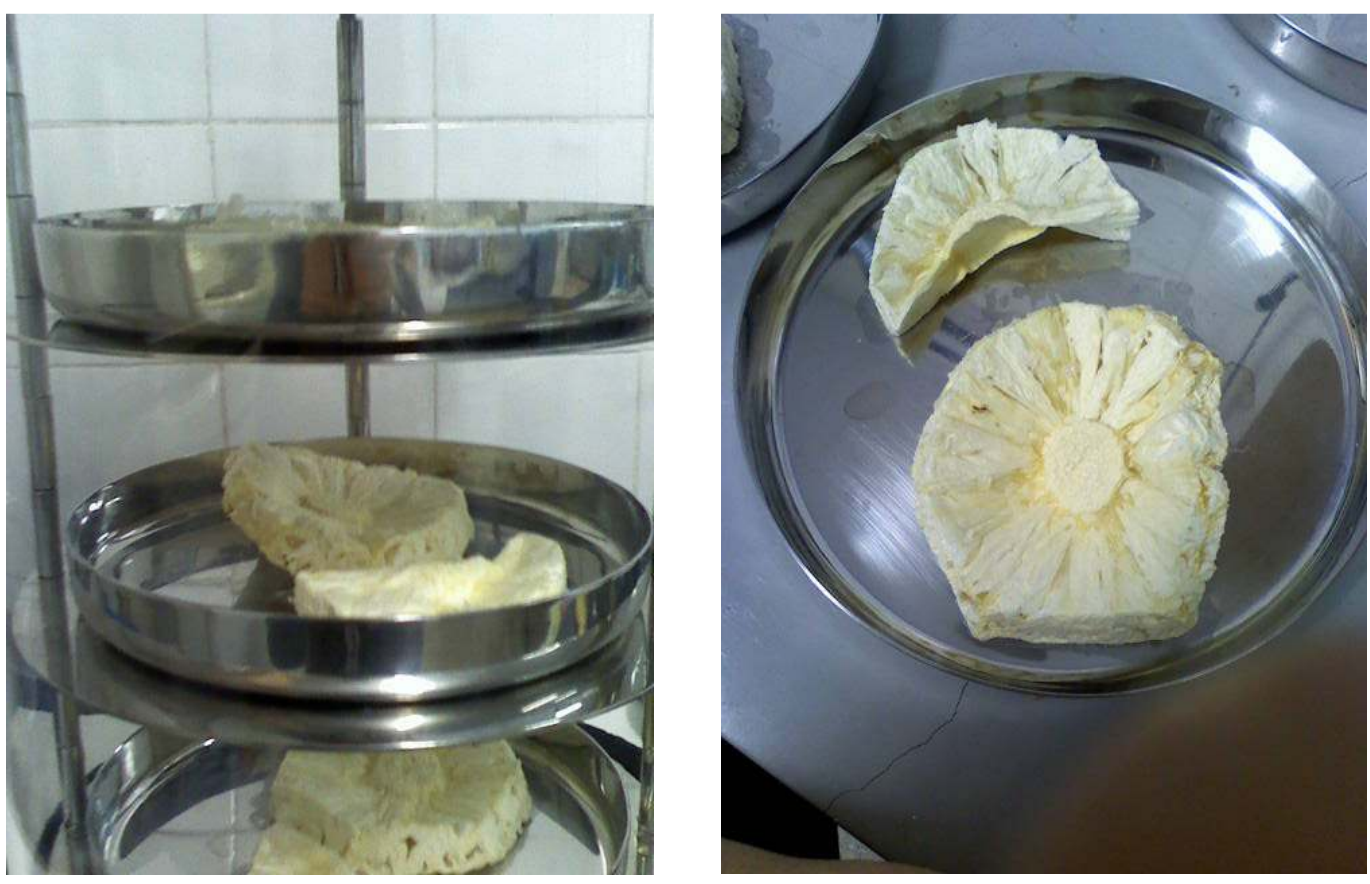

Figura 7. Disposição das fatias nas bandejas do liofilizador. 


\subsection{Determinação de umidade}

A umidade das amostras foi determinada, em triplicata, pelo método gravimétrico, com secagem em estufa a vácuo (Marconi, modelo MA 030) a $60{ }^{\circ} \mathrm{C}$ por 48 horas. As pesagens foram feitas em balança analítica (Chyo, modelo JK 200).

\subsection{Cinética de secagem}

A determinação da cinética de secagem foi conduzida a partir das amostras colocadas nos frascos laterais do liofilizador, o que possibilitou a retirada de amostras em diferentes intervalos de tempo, com o alivio de vácuo, sem interferência nas demais amostras. Para a obtenção da cinética de secagem, antes de serem congeladas as fatias de abacaxi foram divididas em quatro partes, sendo descartado o miolo central. Após o congelamento, cada amostra foi identificada e pesada antes de ser introduzida no liofilizador, permanecendo no mesmo por diferentes intervalos de tempo. A cada intervalo de tempo, um dos frascos era desconectado do liofilizador e a respectiva amostra era novamente pesada. A partir dos dados da umidade inicial das amostras e da variação de peso observada durante a liofilização, foi possível determinar curvas de secagem para as diferentes condições de espessura das fatias e temperaturas de congelamento das mesmas.

\subsection{Vitamina $C$}

Os teores de vitamina $\mathrm{C}$ das amostras frescas e imediatamente após a liofilização foram determinados por titulação com 2,6-diclorofenolindofenol, de acordo com o procedimento descrito a seguir. 
Pesou-se $25 \mathrm{~g}$ de amostra, à qual foram adicionados $50 \mathrm{~mL}$ de uma solução de ácido oxálico $2 \%(\mathrm{p} / \mathrm{v})$. O material foi homogeneizado e, desta mistura (amostra + solução) pesouse uma alíquota de $20 \mathrm{~g}$. Essa alíquota foi diluída posteriormente com o mesmo solvente até atingir um volume de $50 \mathrm{~mL}$ em um balão volumétrico. Filtrou-se a vácuo e retiraram-se em duplicata alíquotas de $10 \mathrm{~mL}$. As alíquotas do filtrado foram tituladas com uma solução de DCFI (2,6-diclorofenolindofenol $0.01 \%$ ) até ser detectado o ponto de viragem, visível pela passagem do incolor a uma coloração rosa (BENASSI; ANTUNES, 1988).

A solução de DCFI $0.01 \%$ foi preparada com $100 \mathrm{mg}$ de 2.6-diclorofenolindofenol diluído em $50 \mathrm{~mL}$ de água destilada em estado pré-fervura, os quais foram transferidos para um balão volumétrico de $1 \mathrm{~L}$, completando-se o volume com água destilada já contendo 210 mg de bicarbonato de sódio.

A solução padrão de ácido ascórbico foi preparada com 125 mg de ácido ascórbico de grau analítico, diluído com ácido oxálico em um balão volumétrico de $50 \mathrm{~mL}$. O valor do DCFI padrão foi quantificado pela titulação da solução de DCFI $0.01 \%$ com a solução de ácido ascórbico. A padronização do DCFI se deu tomando $1 \mathrm{~mL}$ da solução padrão de ácido ascórbico e completando em um balão volumétrico de $25 \mathrm{~mL}$ com ácido oxálico $2 \%$, de onde foram retiradas duas alíquotas de $10 \mathrm{~mL}$ para a titulação com DCFI $0.01 \%$.

Para o cálculo do conteúdo de vitamina $\mathrm{C}$ utilizou-se a seguinte equação:

$$
\begin{aligned}
& \text { DCFI (m solvente + } \\
& \frac{\mathrm{mg} \text { de Vit } \mathrm{C}}{100 \mathrm{~g} \text { de amostra }} \equiv \frac{\text { amostra }(\mathrm{mL})}{\mathrm{DCFI}} \frac{100 \mathrm{~g}}{\mathrm{~m} \text { amostra }} \frac{\mathrm{m} \text { amostra })(\mathrm{g})}{\mathrm{m} \text { alíquota }(\mathrm{g})} \frac{50 \mathrm{~mL}}{V \text { alíquota }(\mathrm{mL})} \\
& \text { padrão }(\mathrm{mL})
\end{aligned}
$$

\subsection{Reidratação}

Após a liofilização das amostras, as mesmas foram cortadas com auxílio de uma faca em aço inoxidável em tamanhos uniformes $(1,5 \times 1,5 \mathrm{~cm})$ para serem armazenadas em 
dessecadores contendo solução saturada de $\mathrm{K}_{2} \mathrm{CO}_{3}$, de modo a manter a umidade relativa do ar no interior do dessecador em um valor constante, igual a 0,432 .

Antes do uso, os dessecadores foram desinfetados passando-se um algodão embebido em água sanitária comercial. A solução salina foi adicionada até uma altura de cerca de $1 \mathrm{~cm}$ a partir do fundo, sendo adicionadas 3 gotas de formol de forma a evitar a deterioração das amostras por estarem em condições de alta umidade. As amostras, de peso inicial conhecido, foram então introduzidas nos dessecadores, sem entrar em contato com a solução salina. Fezse a pesagem das amostras em diversos intervalos de tempo, até que as mesmas entrassem em equilíbrio.

Ao atingirem peso constante, as amostras foram pesadas e em seguida transferidas para um béquer, onde se introduziu um volume de $100 \mathrm{~mL}$ de água destilada. $\mathrm{O}$ tempo de reidratação das amostras foi estabelecido em 5 minutos em temperatura ambiente, sendo, em seguida, levemente enxugadas em papel absorvente e colocadas em repouso por 10 minutos, expostas ao ar ambiente. O peso das amostras reidratadas foi registrado e o índice de reidratação calculado segundo a Equação (3). Os resultados foram obtidos pela média dos índices de reidratação obtidos de cinco réplicas.

\subsection{Textura}

Os perfis de textura das amostras liofilizadas e submetidas à etapa de condicionamento em umidade relativa constante $(U R=0,432)$ foram determinados seguindo a metodologia de Análise de Perfil de Textura (TPA), em um texturômetro TA - XT2i (Texture Analyzer, Stable Micro Sistems) com um probe circular de acrílico de $35 \mathrm{~mm}$ de diâmetro (Figura 8).

Os parâmetros empregados nos testes de TPA foram: 10\% de deformação, velocidade de compressão de $1 \mathrm{~mm} / \mathrm{s}$ e tempo entre as duas compressões de 2 segundos. Os resultados 
dos testes das amostras individuais foram calculados automaticamente pelo programa Texture Expert V. 1.22 (Stable Micro Systems), sendo obtida uma média de cinco amostras para cada ensaio de liofilização.

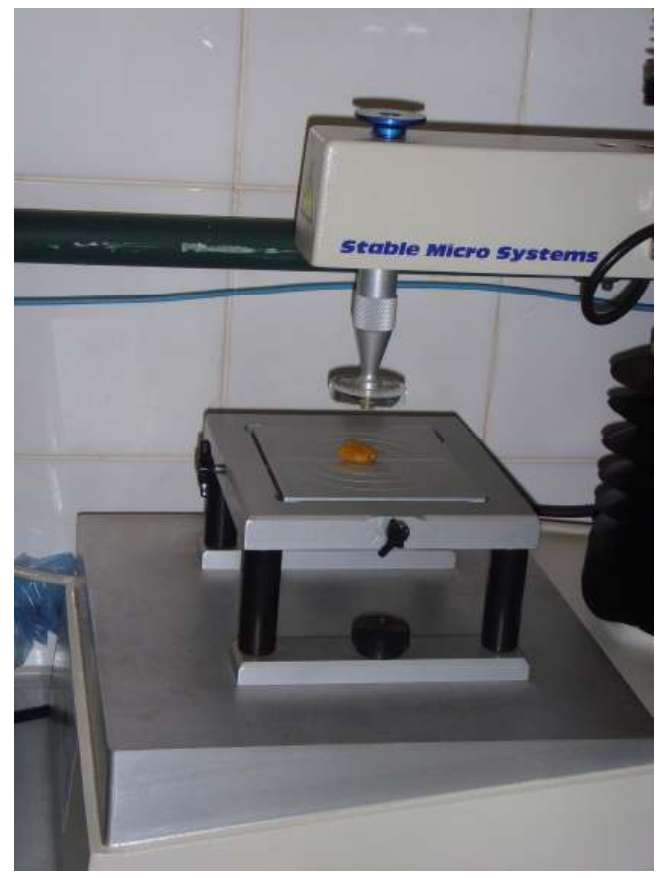

Figura 8. Texturômetro e probe utilizado nos ensaios de TPA das amostras liofilizadas. 


\section{RESULTADOS E DISCUSSÕES}

\subsection{Taxa de congelamento}

Através da variação da espessura das fatias de abacaxi e da temperatura do meio de congelamento, foram obtidas diferentes taxas de congelamento nos ensaios realizados nas condições indicadas na Tabela 3. As curvas de congelamento obtidas para cada ensaio são apresentadas nas Figuras 9, 10 e 11, em função da espessura das fatias de abacaxi, em diferentes temperaturas de congelamento de $-14{ }^{\circ} \mathrm{C},-24{ }^{\circ} \mathrm{C}$ e $-34{ }^{\circ} \mathrm{C}$ respectivamente.

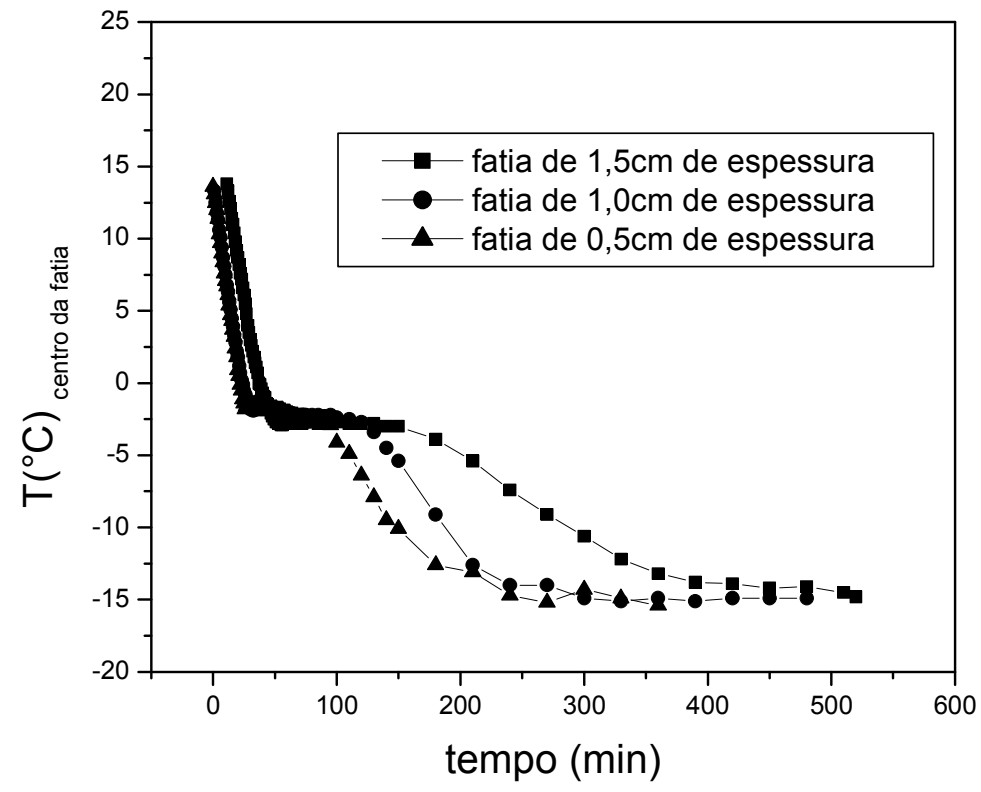

Figura 9. Perfis da temperatura no centro das fatias de diferentes espessuras congeladas a -14 ${ }^{\circ} \mathrm{C}$. 


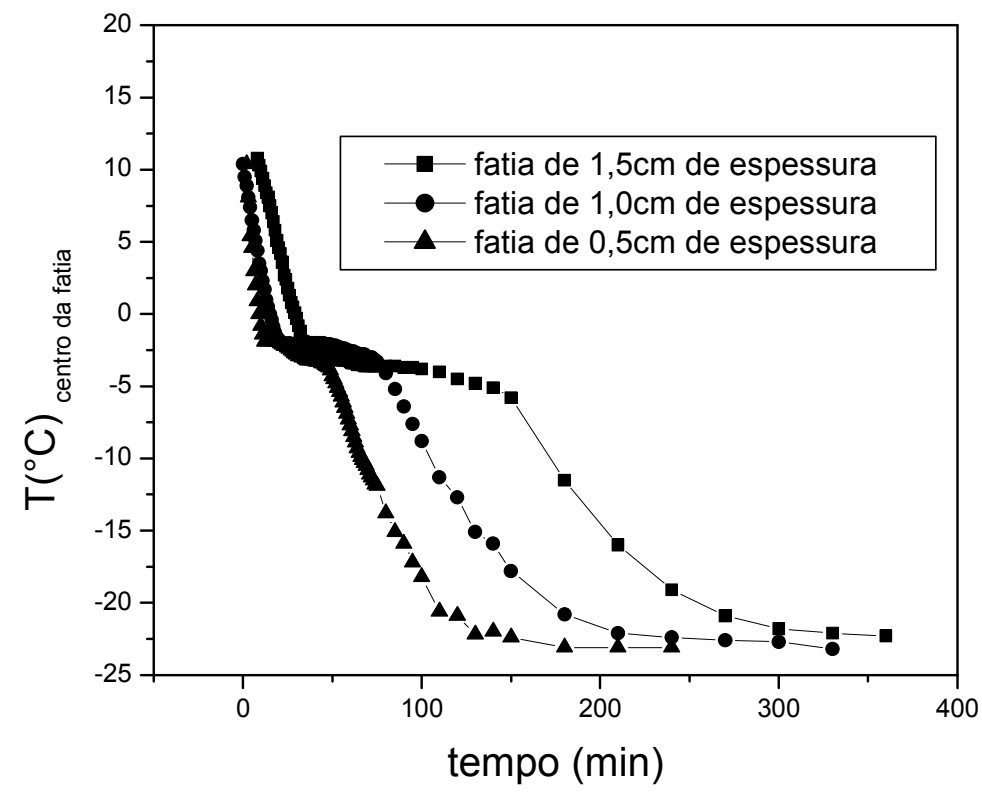

Figura 10. Perfis da temperatura no centro das fatias de diferentes espessuras congeladas a $24{ }^{\circ} \mathrm{C}$.

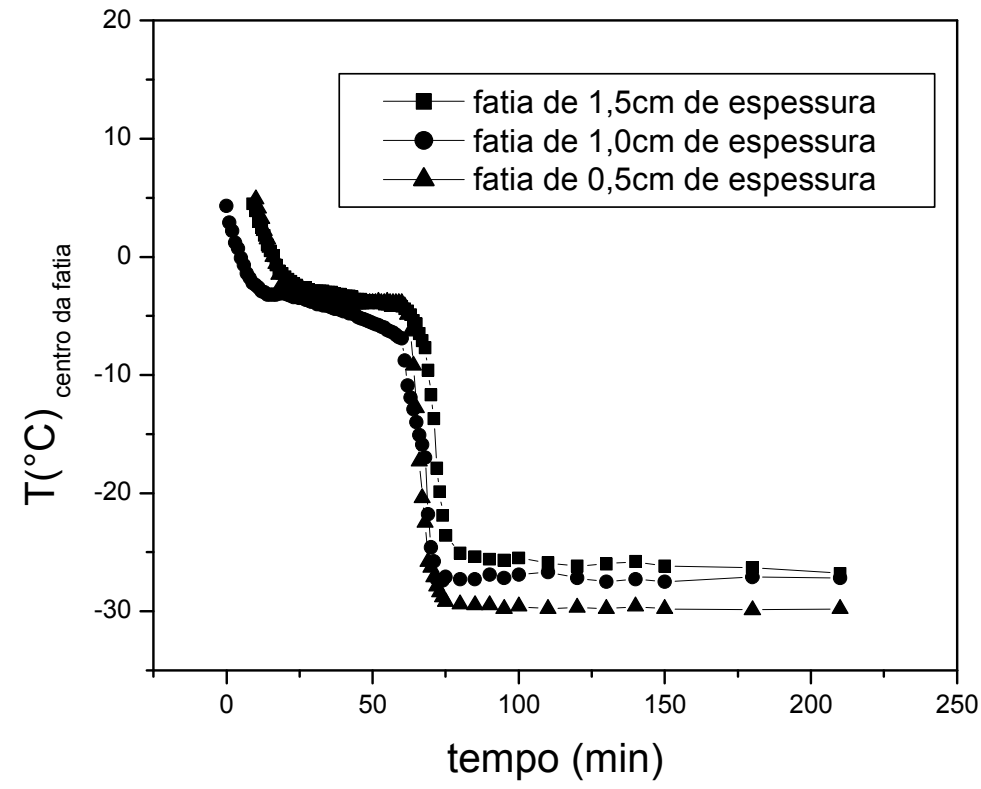

Figura 11. Perfis da temperatura no centro das fatias de diferentes espessuras congeladas a $34{ }^{\circ} \mathrm{C}$. 
Analisando as Figuras 9, 10 e 11, observou-se que, como já era esperado, quanto menor a temperatura de congelamento, mais rapidamente as fatias entram em equilíbrio, ou seja, a temperatura do centro das fatias alcança mais rapidamente o equilíbrio térmico com altas temperaturas de congelamento. Fato também observado em relação à espessura da amostra, que apresentou o congelamento mais lento com as maiores espessuras. Em todas as curvas foi possível detectar o início do platô de temperatura constante, correspondendo à temperatura de início de congelamento, bem como o subseqüente decréscimo da temperatura de congelamento à medida que ocorre a concentração de solutos no interior da amostra, causada pela cristalização da água presente.

Através das curvas de congelamento foi possível calcular a taxa de congelamento atingida em cada ensaio, de acordo com a seguinte equação (MARQUES; FERREIRA; FREIRE, 2007):

$$
\theta=\frac{\left(0-T_{f}\right)}{\Delta t}
$$

onde $\theta$ é a taxa de congelamento, dada em ${ }^{\circ} \mathrm{C} / \mathrm{min}, T_{f}$ é a temperatura de equilíbrio ao final do congelamento e $\Delta t$ é o intervalo de tempo necessário para que o centro térmico da amostra passe de $T=0{ }^{\circ} \mathrm{C}$ para $T=T_{f}$. As taxas de congelamento assim calculadas para cada ensaio são apresentadas na Tabela 4.

A partir dos resultados da Tabela 4, construiu-se um gráfico de superfície (Figura 12), mostrando a variação da taxa de congelamento em função da espessura da fatia e da temperatura de congelamento, onde é possível uma melhor visualização do efeito dessas duas variáveis. A análise de variância (ANOVA) mostrou que ambas as variáveis independentes apresentaram efeito linear (L) significativo ao nível de $95 \%(\mathrm{p}<0,05)$. Os resultados da ANOVA são apresentados na Tabela 5. 
Tabela 4. Taxas de congelamento calculadas pela Equação (4) para fatias de abacaxi de diferentes espessuras, congeladas em diferentes temperaturas.

\begin{tabular}{cccccc}
\hline Ensaio & $\begin{array}{c}\text { Espessura } \\
\text { da fatia } \\
(\mathbf{c m})\end{array}$ & $\begin{array}{c}\text { Temperatura de } \\
\text { congelamento } \\
\mathbf{(} \mathbf{C} \text { C) }\end{array}$ & $\begin{array}{c}\text { Umidade } \\
\text { inicial } \\
(\mathbf{b . u} .)\end{array}$ & ${ }^{\circ}$ Brix & $\begin{array}{c}\text { Taxa de } \\
\text { congelamento } \\
\left({ }^{\circ} \mathbf{C} / \text { min) }\right.\end{array}$ \\
\hline 1 & 0,5 & -14 & 0,8834 & 10,2 & 0,067 \\
2 & 1,0 & -14 & 0,8852 & 11,1 & 0,054 \\
3 & 1,5 & -14 & 0,8568 & 10,7 & 0,031 \\
4 & 0,5 & -24 & 0,8505 & 16,7 & 0,135 \\
5 & 1,0 & -24 & 0,8110 & 19,7 & 0,074 \\
6 & 1,5 & -24 & 0,8118 & 17,9 & 0,067 \\
7 & 0,5 & -34 & 0,8317 & 13,8 & 0,377 \\
8 & 1,0 & -34 & 0,8630 & 12,2 & 0,220 \\
9 & 1,5 & -34 & 0,8145 & 13,7 & 0,138 \\
\hline
\end{tabular}

Tabela 5. Análise de variância dos dados de taxa de congelamento em função da espessura da fatia e da temperatura de congelamento.

\begin{tabular}{lccccc}
\hline \multicolumn{1}{c}{ Fator } & SQ & GL & QM & F & p \\
\hline Temperatura (L) & 0,0542 & 1 & 0,0542 & 15,89 & 0,0072 \\
Espessura (L) & 0,0212 & 1 & 0,0212 & 6,21 & 0,0471 \\
Erro & 0,0205 & 6 & 0,0034 & & \\
SQ total & 0,0959 & 8 & & & \\
\hline
\end{tabular}

SQ: Soma dos quadrados dos resíduos; GL: Graus de liberdade; QM: Quadrado médio.

Como esperado, houve um aumento nas taxas de congelamento com a redução da temperatura de congelamento e com a diminuição da espessura das fatias, o que reflete o aumento do potencial e a diminuição da resistência à transferência de calor, respectivamente. No entanto, todas as condições de congelamento testadas neste trabalho podem ser classificadas como sendo condições de congelamento lento. 


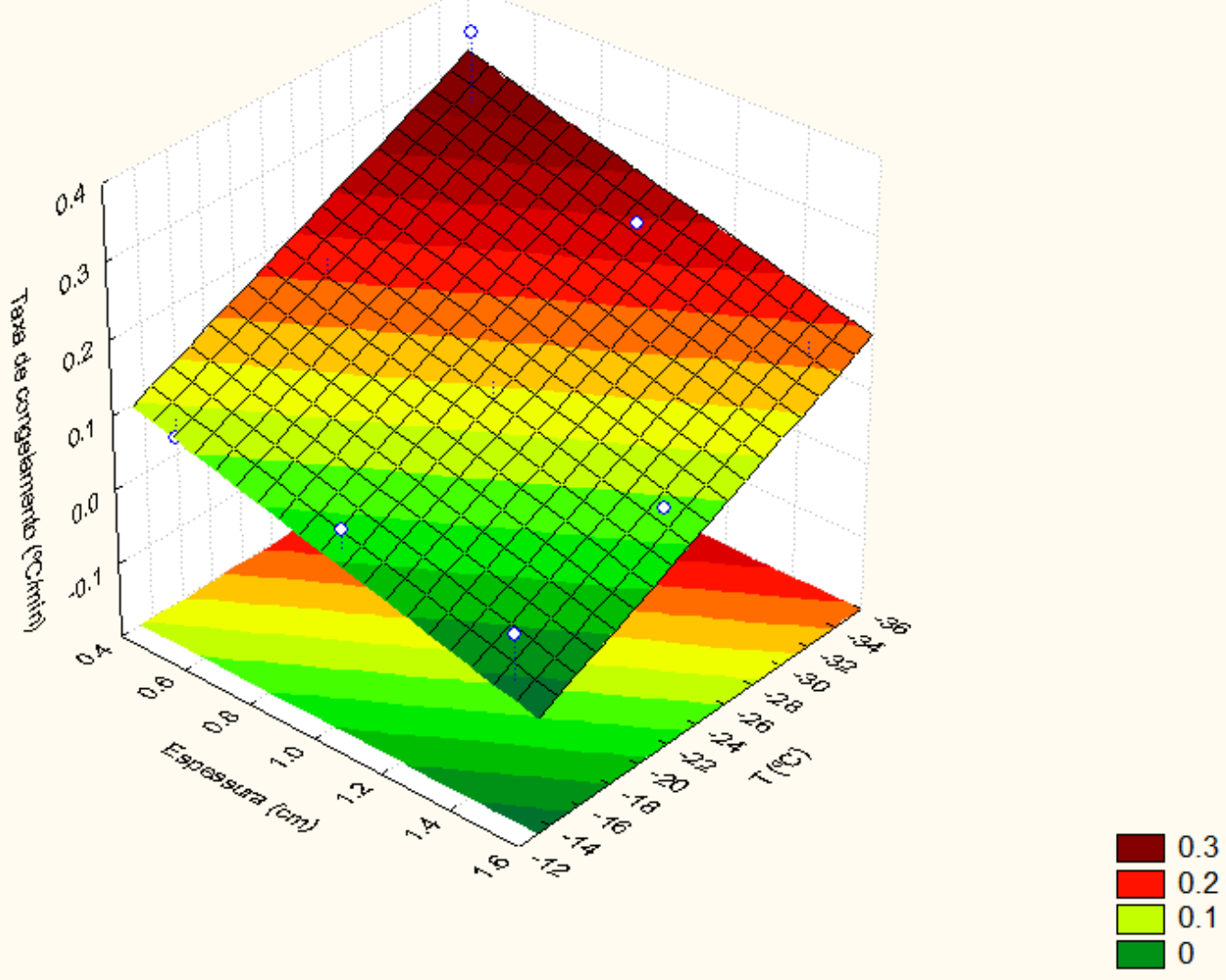

Figura 12. Efeitos da espessura das fatias e da temperatura de congelamento sobre a taxa de congelamento.

A taxa de congelamento é um parâmetro importante que precisa ser definido durante o congelamento. O grau de alterações estruturais induzidas pelo congelamento em um determinado produto alimentício é uma função complexa, tanto da taxa de congelamento quanto da temperatura final obtida. Os efeitos relacionados com as taxas de congelamento na estabilidade dos biopolímeros variam de forma significativa. De acordo com Murgatroyd et al. (1997), o congelamento é uma das etapas mais críticas do processo de liofilização.

Tattini Jr., Parra e Pitombo (2006) concluíram que a albumina bovina liofilizada com taxa de congelamento alta $\left(30^{\circ} \mathrm{C} / \mathrm{min}\right)$ apresentou desdobramento estrutural durante a 
liofilização, mas recuperou a conformação original após a reidratação (desdobramento reversível); no entanto, a albumina bovina liofilizada com taxa de congelamento lento $(2,5$ ${ }^{\circ} \mathrm{C} / \mathrm{min}$ ) apresentou desdobramento estrutural durante a liofilização e agregação após a reidratação (desdobramento irreversível), característica desfavorável em relação à manutenção da estrutura secundária da proteína. Logo o congelamento lento favoreceu a eliminação da água estrutural da albumina bovina nativa diminuindo o tempo de secagem durante a liofilização, porém prejudicando a estrutura conformacional da molécula.

\subsection{Cinética de Secagem}

A partir dos ensaios de liofilização das fatias de abacaxi submetidas a diferentes condições de congelamento, foram construídas curvas de secagem, isto é, curvas de umidade em função do tempo, com o objetivo de avaliar a influência da variação da taxa de congelamento sobre a cinética de secagem. Os resultados são apresentados nas Figuras 13, 14 e 15, em função da espessura das fatias de abacaxi, em diferentes temperaturas de congelamento de $-14{ }^{\circ} \mathrm{C},-24{ }^{\circ} \mathrm{C}$ e $-34{ }^{\circ} \mathrm{C}$ respectivamente.

Nessas figuras, a umidade em função do tempo, $X$, é representada em relação à umidade inicial do produto, $X_{0}$, isto é, considerando a umidade de equilíbrio, $X_{e q}$ (Equação 2) como aproximadamente igual a zero. 


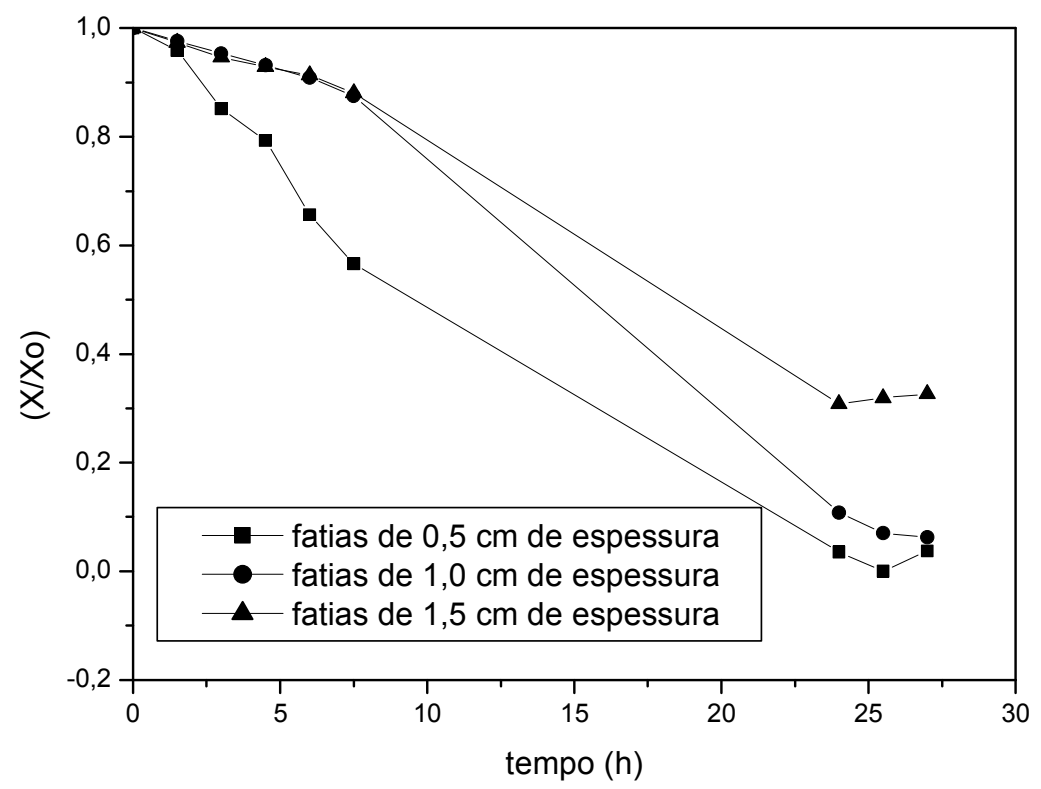

Figura 13. Curvas de secagem de fatias de diferentes espessuras congeladas à temperatura de $-14{ }^{\circ} \mathrm{C}$.

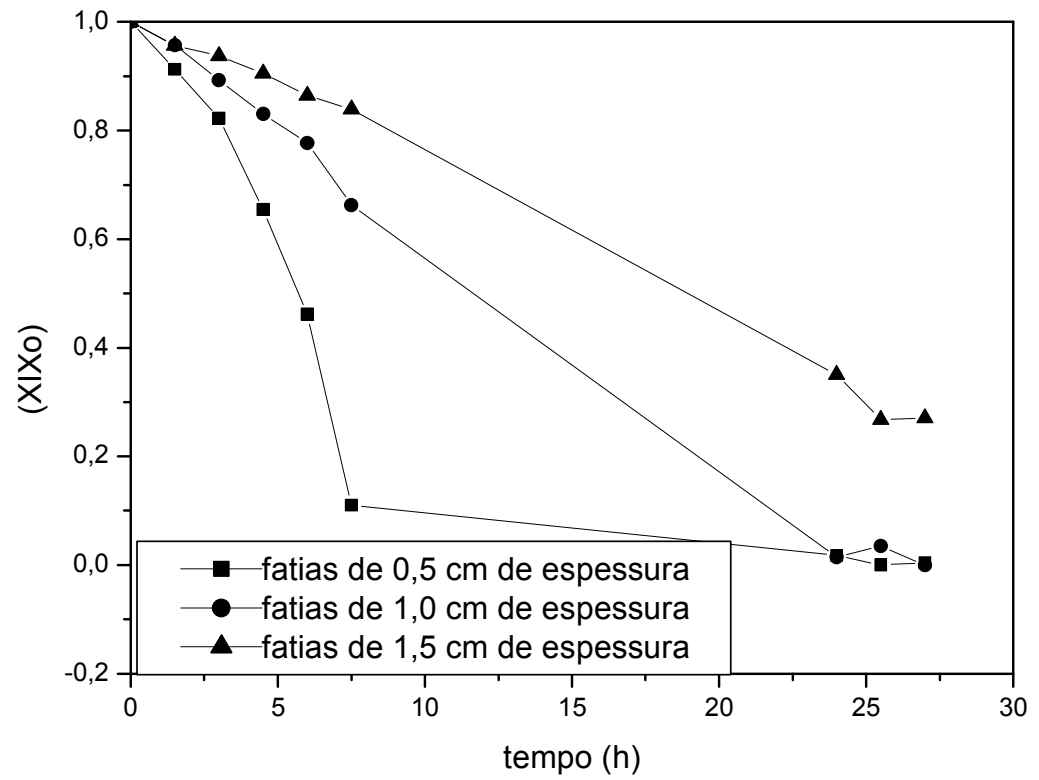

Figura 14. Curvas de secagem de fatias de diferentes espessuras congeladas à temperatura de $-24{ }^{\circ} \mathrm{C}$. 


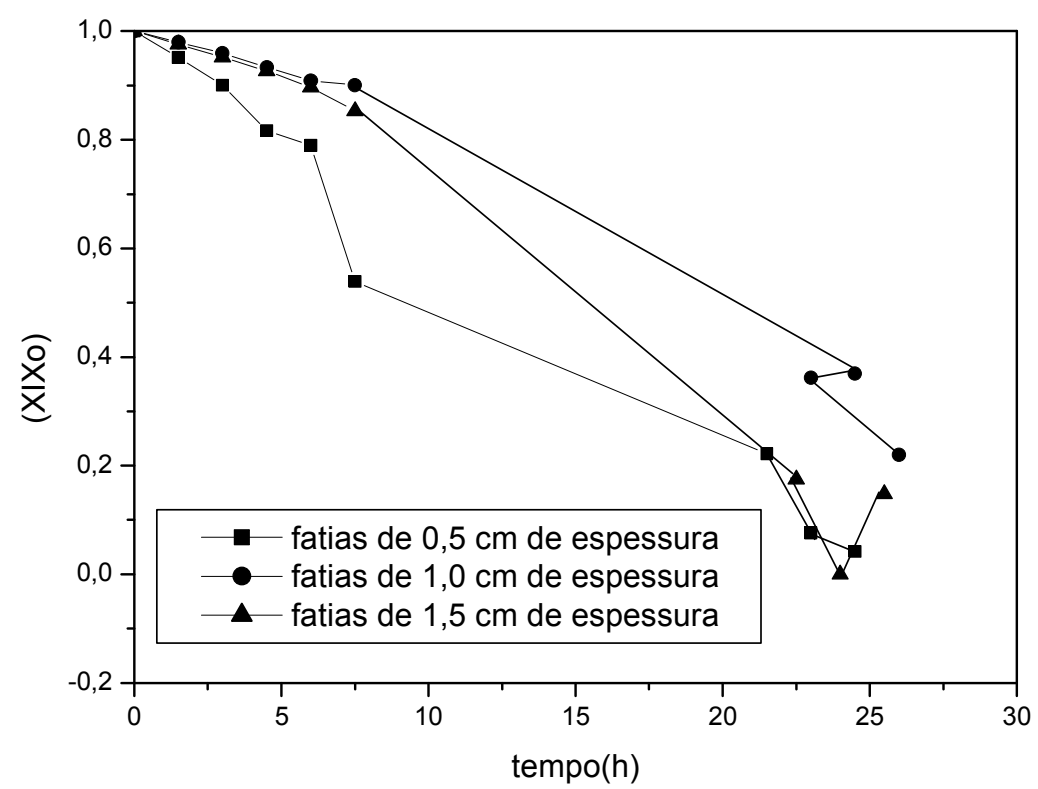

Figura 15. Curvas de secagem de fatias de diferentes espessuras congeladas à temperatura de $-34{ }^{\circ} \mathrm{C}$.

Considerando que o número de amostras para determinação das curvas de secagem era limitado pelo número máximo de frascos que poderiam ser conectados ao liofilizador (um máximo de 8 frascos), houve necessidade de estabelecer intervalos de tempo relativamente grandes para a retirada de amostras. Mesmo assim, a partir dos dados obtidos, foi possível observar claramente o comportamento das curvas de secagem durante a liofilização.

A maior parte das curvas segue a mesma tendência de comportamento em sua parte inicial, de modo que se optou por ajustar a solução da $2^{\underline{a}}$ Lei de Fick para placas planas (Equação 2) aos pontos correspondentes às 7,5 horas iniciais da secagem, de modo a estabelecer uma comparação dos efeitos das condições de congelamento utilizadas sobre a difusividade efetiva $\left(D_{e f}\right)$ da água nas fatias de abacaxi durante o início da liofilização.

Considerou-se apenas o primeiro termo da série infinita dada pela Equação (2), o qual pode ser linearizado, permitindo o cálculo da difusividade efetiva a partir do valor do 
coeficiente angular das curvas de $\ln \left(X / X_{0}\right)$ em função do tempo, $t$. Esse procedimento foi aplicado, por regressão linear, aos pontos experimentais da parte inicial $(t \leq 7,5 \mathrm{~h})$ de cada uma das curvas de secagem. Para o cálculo da difusividade efetiva a partir do coeficiente angular obtido, foi considerado o fato de que apenas uma das faces das fatias era exposta à transferência de massa durante a liofilização, sendo então introduzido o valor de duas vezes a espessura da fatia. Os resultados do ajuste estão apresentados nas Figuras 16, 17 e 18, enquanto os valores calculados para a difusividade efetiva encontram-se na Tabela 6 . Através dos valores dos coeficientes de determinação, $R^{2} \geq 0,90$, apresentados na Tabela 6 , pode-se considerar que a solução da $2^{\underline{a}}$ Lei de Fick linearizada apresentou um bom ajuste aos dados experimentais correspondentes ao início do processo de liofilização.

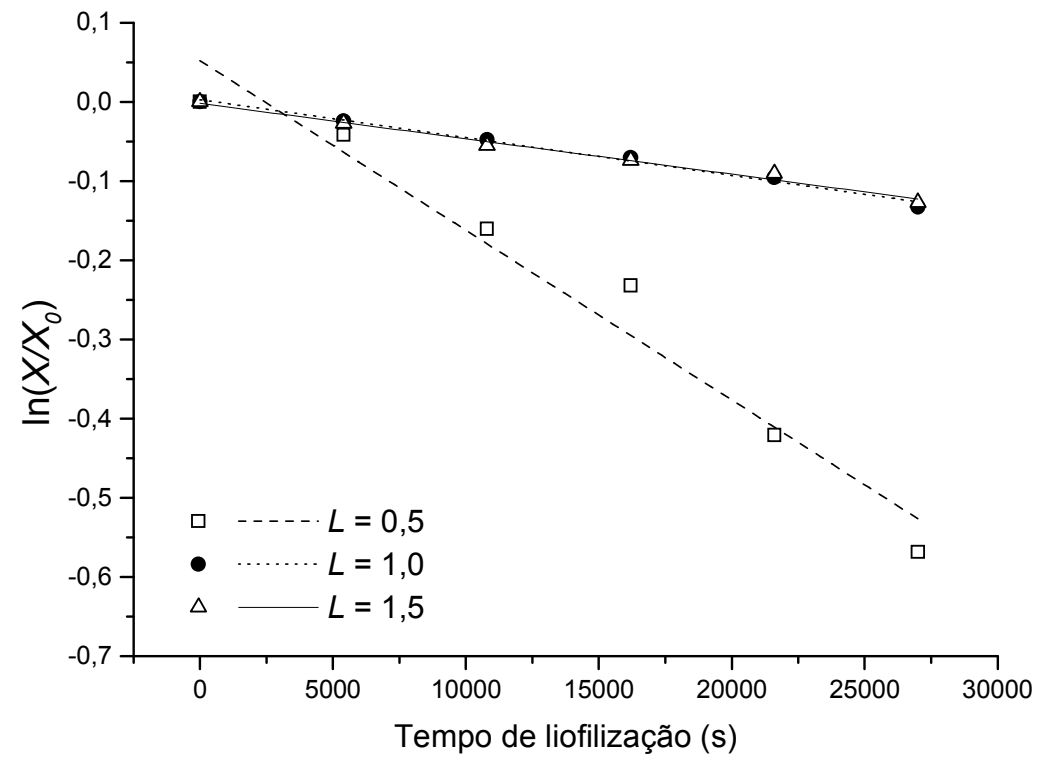

Figura 16. Ajustes da Equação (2) às curvas de secagem à temperatura de $-14{ }^{\circ} \mathrm{C}$ para $t \leq 7,5$ h. 


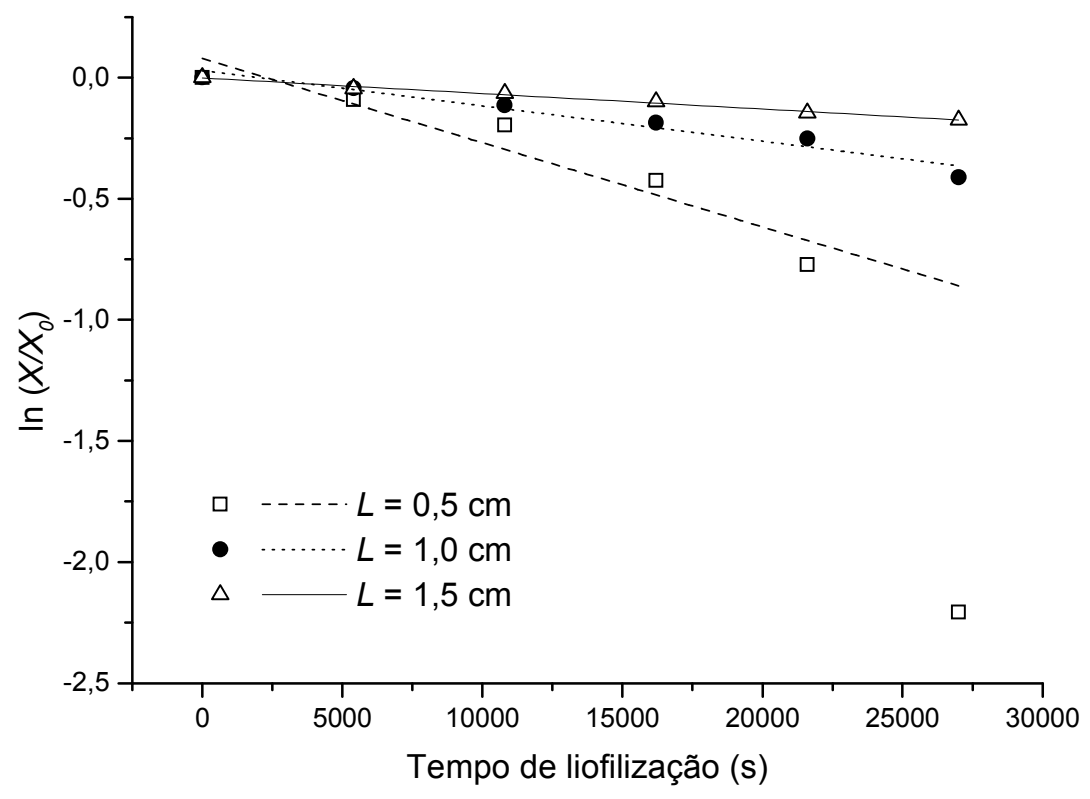

Figura 17. Ajustes da Equação (2) às curvas de secagem à temperatura de $-24^{\circ} \mathrm{C}$ para $t \leq 7,5$ h.

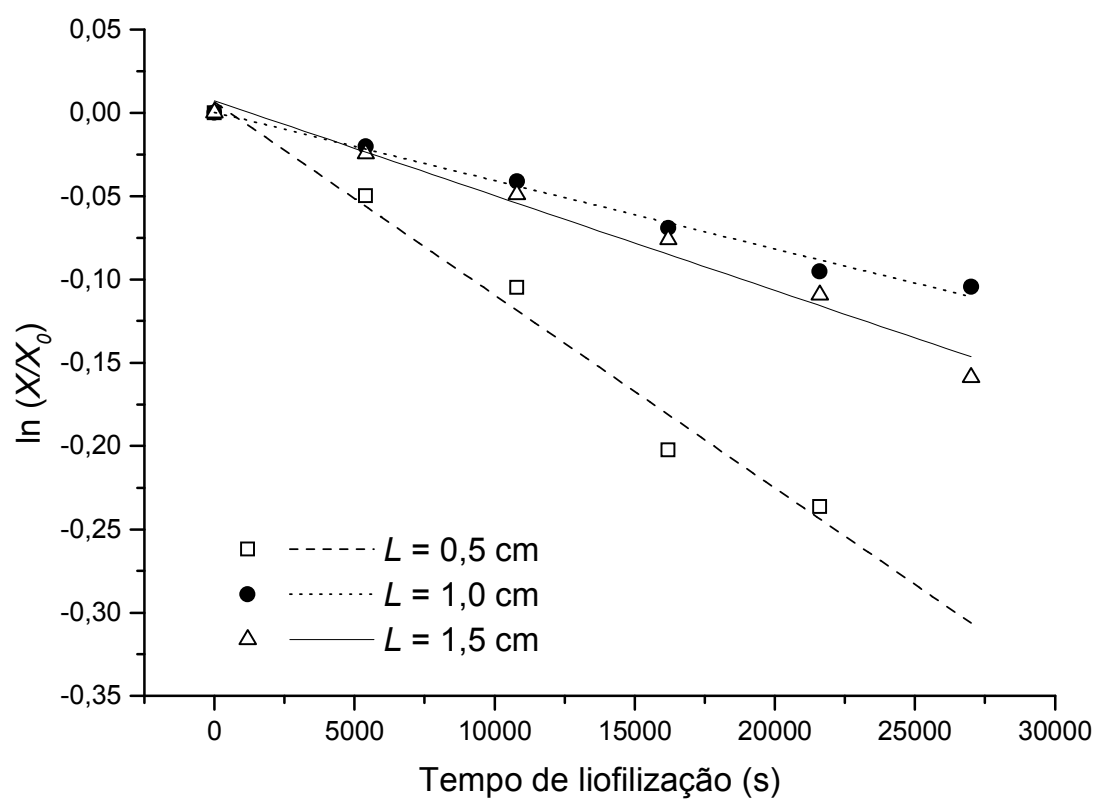

Figura 18. Ajustes da Equação (2) às curvas de secagem à temperatura de $-34{ }^{\circ} \mathrm{C}$ para $t \leq 7,5$ h. 
Tabela 6. Valores de difusividade efetiva obtidos pelo ajuste da 2a Lei de Fick linearizada ao período inicial da liofilização $(\mathrm{t} \leq 7,5 \mathrm{~h})$.

\begin{tabular}{cccc}
\hline $\begin{array}{c}\text { Temperatura } \\
\left({ }^{\circ} \mathbf{C}\right)\end{array}$ & $\begin{array}{c}\text { Espessura } \\
(\mathbf{c m})\end{array}$ & $\begin{array}{c}\text { Difusividade Efetiva } \\
\left(\boldsymbol{D}_{\text {ef }} \mathbf{x} \mathbf{1 0}^{\mathbf{1 0}}, \mathbf{~ m}^{\mathbf{2}} / \mathbf{s}\right)\end{array}$ & $\begin{array}{c}\text { Coeficiente de } \\
\text { Determinação }\left(\boldsymbol{R}^{\mathbf{2}}\right)\end{array}$ \\
\hline-14 & 0,5 & 2,17 & 0,961 \\
-14 & 1,0 & 1,93 & 0,992 \\
-14 & 1,5 & 4,08 & 0,989 \\
\hline-24 & 0,5 & 3,52 & 0,920 \\
-24 & 1,0 & 5,90 & 0,957 \\
-24 & 1,5 & 5,85 & 0,992 \\
\hline-34 & 0,5 & 1,17 & 0,981 \\
-34 & 1,0 & 1,66 & 0,988 \\
-34 & 1,5 & 5,19 & 0,979 \\
\hline
\end{tabular}

Os valores obtidos para a difusividade efetiva, da ordem de $10^{-10} \mathrm{~m}^{2} / \mathrm{s}$, têm ordem de grandeza equivalente àqueles obtidos por Nicoleti et al. (2001) para fatias de abacaxi desidratadas por ar quente. Isso mostra que, ao menos no início, a liofilização apresenta taxas de secagem similares à secagem por convecção forçada de ar quente.

Nicoleti et al. (2001) observou o comportamento da difusividade efetiva para o abacaxi in natura e pré-tratado osmóticamente, nas mesmas condições de secagem, e concluiu que a resistência à transferência de massa é maior para o material submetido ao tratamento osmótico.

A difusividade efetiva engloba os efeitos de todos os fenômenos que podem intervir sobre a migração da água, e seu valor é sempre obtido pelo ajuste de valores experimentais. A solução da equação de difusão utilizada é uma das mais simples e parece ser a principal razão de seu emprego. Pode-se entender a difusividade como a facilidade com que a água é removida do material. Como a difusividade assim calculada varia conforme mudam as condições de secagem, ela não é intrínseca ao material, assim, convenciona-se chamá-la de difusividade efetiva (OLIVEIRA; OLIVEIRA; PARK; 2006). 
A análise dos efeitos das condições de congelamento sobre a difusividade efetiva pode ser feita de forma mais abrangente a partir do gráfico de superfície, apresentado na Figura 19. Através da análise de variância (Tabela 7), verificou-se que tanto a espessura das fatias quanto a temperatura de congelamento tiveram efeitos significativos sobre a difusividade efetiva $(\mathrm{p}<$ $0,05)$.

Tabela 7. Análise de variância dos dados de difusividade efetiva em função da espessura da fatia e da temperatura de congelamento.

\begin{tabular}{lccccc}
\hline \multicolumn{1}{c}{ Fator } & SQ & GL & QM & F & p \\
\hline Temperatura (L+Q) & $1,14 \times 10^{-19}$ & 2 & $5,72 \times 10^{-20}$ & 6,06 & 0,046 \\
Espessura (L) & $1,13 \times 10^{-19}$ & 1 & $1,13 \times 10^{-19}$ & 12,0 & 0,018 \\
Erro & $4,72 \times 10^{-20}$ & 5 & $9,44 \times 10^{-19}$ & & \\
SQ total & $2,75 \times 10^{-19}$ & 8 & & & \\
\hline
\end{tabular}

SQ: Soma dos quadrados dos resíduos; GL: Graus de liberdade; QM: Quadrado médio. 


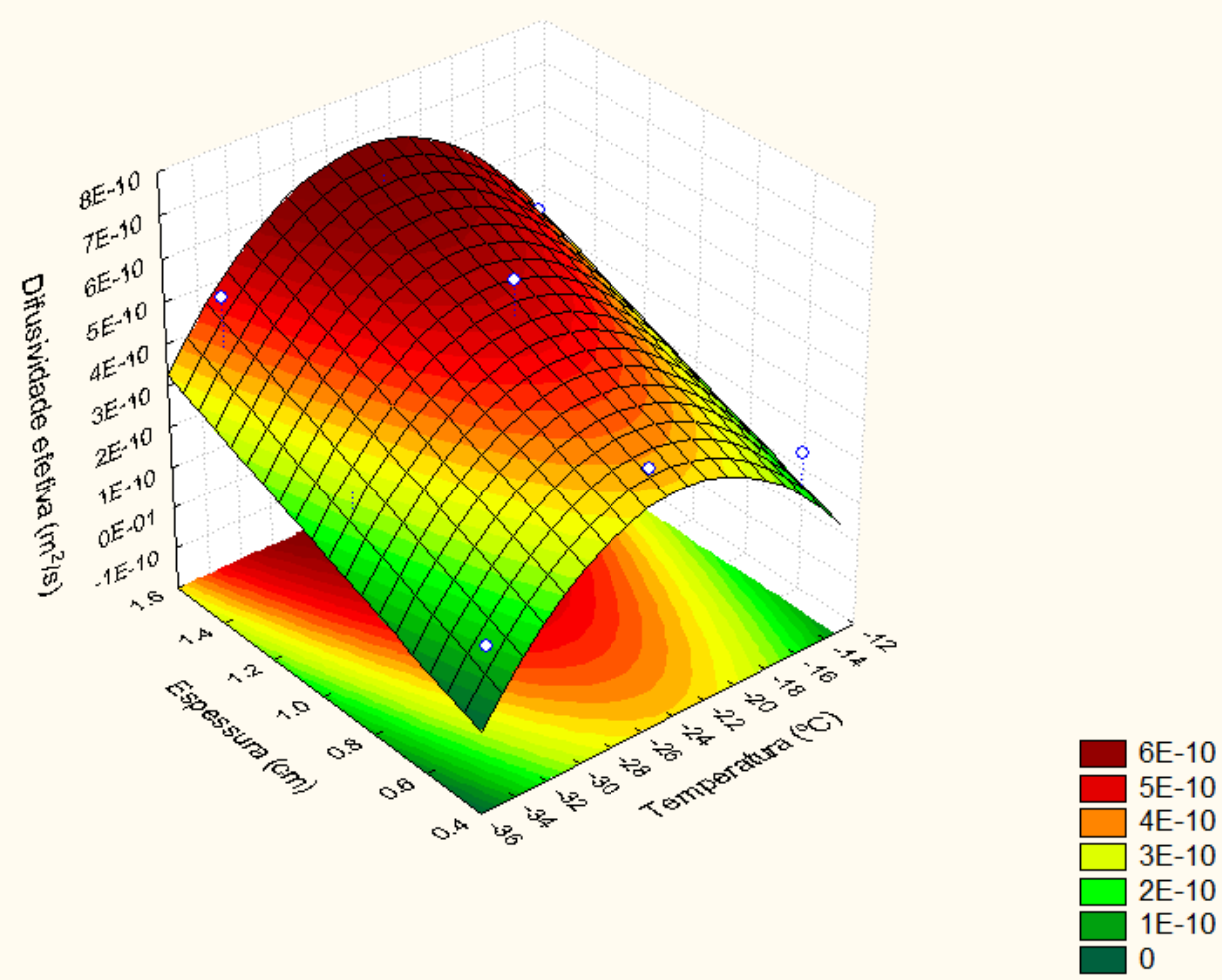

Figura 19. Efeitos da espessura das fatias e da temperatura de congelamento sobre a difusividade efetiva do período inicial da liofilização $(t \leq 7,5 \mathrm{~h})$.

Observa-se, na Figura 19, que a difusividade efetiva correspondente ao período inicial da liofilização $(t \leq 7,5 \mathrm{~h})$ foi fortemente influenciada pelas condições de congelamento da fatia, já que estas se refletem na taxa de congelamento. Como já foi dito, a taxa de congelamento tem grande influência sobre a distribuição dos poros no material a ser seco e, conseqüentemente, influencia as taxas de transferência de massa.

Em relação ao efeito da espessura das fatias, a Figura 19 mostra que a difusividade foi maior nas fatias de maior espessura, o que pode estar relacionado ao fato de que, nessas condições as taxas de congelamento foram menores, gerando cristais maiores e deixando o produto com poros também maiores. 
Por outro lado, quanto ao efeito da temperatura, os maiores valores de difusividade foram observados na temperatura de congelamento intermediária $\left(-24{ }^{\circ} \mathrm{C}\right)$. Esse resultado pode estar refletindo a interação de dois fatores: por um lado, na menor temperatura $\left(-34^{\circ} \mathrm{C}\right)$ os cristais formados podem ter sido menores, levando à formação de poros menores e com menor destruição do tecido celular do que no produto congelado a $-24{ }^{\circ} \mathrm{C}$; por outro lado, o congelamento a $-14{ }^{\circ} \mathrm{C}$ pode não ter sido suficiente para congelar uma fração significativa da água presente na fruta, causando o colapso da matriz durante a liofilização e diminuindo a eficiência do processo. Além disso, devido à menor taxa de congelamento e à formação de grandes cristais, originam-se grandes poros, porém em número reduzido, deixando algumas regiões com ausência de poros e, portanto sem vias de transporte de água.

\subsection{Vitamina $\mathrm{C}$}

Os conteúdos médios de vitamina $\mathrm{C}$ determinados para os abacaxis in natura utilizados neste trabalho variaram na faixa de 0,32 a $1,16 \mathrm{mg}$ de Vit $\mathrm{C} / \mathrm{g}$ de matéria seca. A Figura 20 mostra a distribuição dos valores experimentais obtidos nos nove ensaios realizados. 


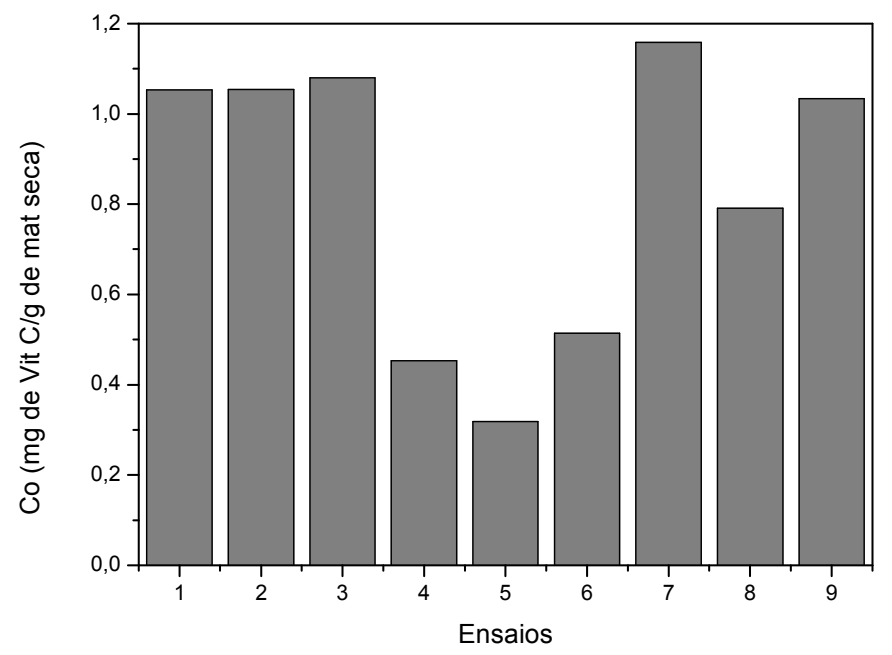

Figura 20. Conteúdo de vitamina $\mathrm{C}$ experimental nos abacaxis in natura utilizados nos ensaios de liofilização.

A Tabela 8 apresenta os valores obtidos para o conteúdo de vitamina $\mathrm{C}$ nas fatias de abacaxi após a liofilização e a porcentagem de retenção em função das condições de congelamento adotadas. A média do conteúdo de vitamina $\mathrm{C}$ retido foi de $70 \%$ de em relação ao conteúdo inicial. Essa porcentagem de retenção é maior do que a observada por Marfil et al. (2008) para secagem por ar quente $\left(50\right.$ a $\left.70{ }^{\circ} \mathrm{C}\right)$ de metades de tomates. Esses autores verificaram uma retenção de vitamina $C$ variando de 10 a $40 \%$ em função da temperatura do ar de secagem, sendo que as maiores perdas ocorreram nas maiores temperaturas de secagem.

Na Tabela 8, alguns valores de retenção de vitamina C (\%) ultrapassam os $100 \%$, fato que pode ser justificado pela diversidade dos frutos em suas características fisiológicas (composição química), lembrando que para cada ensaio eram fatiados de 2 a 3 frutos, e pelos erros associados ao procedimento experimental.

$\mathrm{O}$ efeito das condições de congelamento da amostra sobre a retenção de vitamina $\mathrm{C}$ durante a liofilização está apresentado na Figura 21, que mostra um gráfico de superfície 
representando a porcentagem de retenção de vitamina $\mathrm{C}$ em função da temperatura de congelamento e da espessura da fatia. A análise de variância (Tabela 9) mostrou que nenhum dos efeitos foi significativo ao nível de $95 \%$. Porém, o efeito linear (L) da espessura das fatias mostrou um nível de significância $(93 \%, \mathrm{p}<0,07)$ bem maior do que a temperatura de congelamento $(82 \%, \mathrm{p}<0,18)$.

Tabela 8. Conteúdo de Vitamina $\mathrm{C}$ antes e após a liofilização em função da temperatura de congelamento e as espessuras das amostras.

\begin{tabular}{ccccccc}
\hline $\begin{array}{c}\text { Espessura } \\
\text { da fatia } \\
(\mathbf{c m})\end{array}$ & $\begin{array}{c}\text { Temperatura de } \\
\text { Congelamento } \\
\left({ }^{\circ} \mathbf{C}\right)\end{array}$ & ${ }^{\circ}$ Brix & $\begin{array}{c}\text { Umidade } \\
\text { Final } \\
(\% \text { b.u. })\end{array}$ & $\begin{array}{c}\text { Teor de vit. C } \\
\text { inicial } \\
(\mathbf{m g} / \mathbf{g ~ m s})\end{array}$ & $\begin{array}{c}\text { Teor de vit. C } \\
\text { final } \\
(\mathbf{m g} / \mathbf{g} \text { ms })\end{array}$ & $\begin{array}{c}\text { Retenção } \\
\text { de vit. C } \\
(\%)\end{array}$ \\
\hline 0,5 & -14 & 10,2 & 0,033 & 1,05 & 0,69 & 65,0 \\
1,0 & -14 & 11,1 & 0,056 & 1,05 & 0,35 & 33,5 \\
1,5 & -14 & 10,7 & 0,280 & 1,08 & 0,51 & 47,5 \\
0,5 & -24 & 16,7 & 0,004 & 0,45 & 0,42 & 93,5 \\
1,0 & -24 & 19,7 & 0,001 & 0,32 & 0,33 & 104,5 \\
1,5 & -24 & 17,9 & 0,220 & 0,51 & 0,28 & 53,8 \\
0,5 & -34 & 13,8 & 0,035 & 1,16 & 1,14 & 98,6 \\
1,0 & -34 & 12,2 & 0,190 & 0,79 & 0,79 & 100,3 \\
1,5 & -34 & 13,7 & 0,121 & 1,03 & 0,39 & 37,9 \\
\hline
\end{tabular}

Tabela 9. Análise de variância dos dados de retenção de vitamina $\mathrm{C}$ em função da espessura da fatia e da temperatura de congelamento.

\begin{tabular}{lccccc}
\hline \multicolumn{1}{c}{ Fator } & SQ & GL & QM & F & p \\
\hline Temperatura (L+Q) & 2180,6 & 2 & 1090,3 & 2,56 & 0,172 \\
Espessura (L) & 2318,7 & 1 & 2318,7 & 5,44 & 0,067 \\
Erro & 2132,2 & 5 & 426,4 & & \\
SQ total & 6631,5 & 8 & & & \\
\hline
\end{tabular}

SQ: Soma dos quadrados dos resíduos; GL: Graus de liberdade; QM: Quadrado médio. 


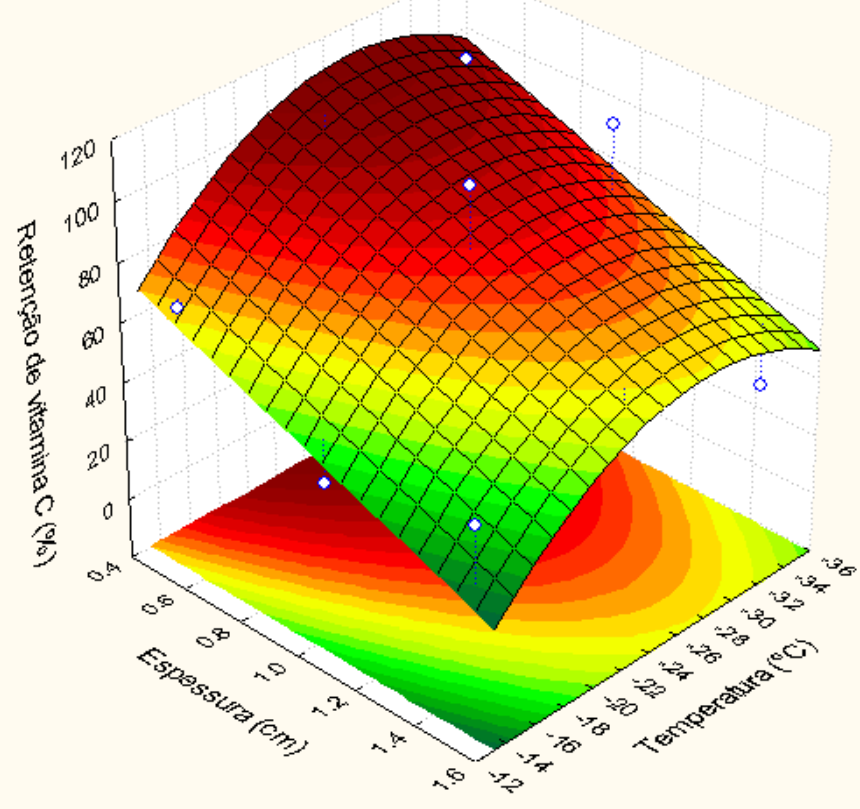

Figura 21. Efeitos da espessura das fatias e da temperatura de congelamento sobre a retenção de vitamina $\mathrm{C}$ durante a liofilização.

Observou-se maior retenção de vitamina $\mathrm{C}$ para as fatias de menor espessura, o que poderia ser atribuído à maior taxa de congelamento e, conseqüentemente, menor tempo de secagem observados nessas condições. Nesse caso, os cristais de gelo formados são menores, levando à menor destruição do tecido celular, favorecendo a preservação do nutriente no interior do produto. Por outro lado, em relação à temperatura de congelamento, esse efeito não é tão claro com um máximo de retenção sendo observado na temperatura intermediária (-24 $\left.{ }^{\circ} \mathrm{C}\right)$. Uma explicação para esse resultado aparentemente contraditório pode ser encontrada analisando a grande variação do teor inicial de vitamina $\mathrm{C}$, bem como o teor de sólidos solúveis das amostras (Figura 20 e Tabela 8), os quais devem estar associados a diferentes estágios de maturação das frutas. Marques, Ferreira e Freire (2007) observaram que a retenção 
de vitamina $\mathrm{C}$ durante o processo de liofilização de acerolas é fortemente dependente do estágio de maturação da fruta, sendo as maiores perdas $(69,3 \%$ e 51,6 \%) observadas para acerolas verdes e completamente maduras, respectivamente. Uma pequena degradação (13 \%) foi verificada para as frutas no estágio de maturação intermediário, o que foi atribuído à instabilidade e sensibilidade do ácido ascórbico (vitamina $\mathrm{C}$ ) à umidade, $\mathrm{pH}$ e íons metálicos, os quais variam com o estágio de maturação da fruta.

Nicoleti et al. (2007) observaram o efeito do tempo e da temperatura sobre a taxa de degradação do ácido ascórbico e concluíram que a perda de nutrientes foi afetada significativamente pela temperatura, considerando que, para atingir a mesma umidade final, as amostras secas em temperaturas mais elevadas foram expostas ao ar quente por um período mais curto de tempo, conseqüentemente a perda de ácido ascórbico (vitamina C) apresentou um aumento acentuado com o aumento da temperatura de secagem, independente do tempo necessário para atingir o conteúdo de umidade desejada.

\subsection{Reidratação}

Os resultados obtidos nos cálculos do índice de reidratação das amostras liofilizadas e acondicionadas em $\mathrm{a}_{\mathrm{w}}=0,432$ são apresentados na Tabela 10. O objetivo dessa etapa inicial de acondicionamento em uma umidade relativa constante foi eliminar o efeito da diferença de umidade entre as amostras após a liofilização, uma vez que, devido à variação das condições de congelamento, a umidade final das amostras também variou, como mostra a Tabela 8 .

Os índices de reidratação obtidos variaram na faixa de 1,08 a 1,71, ficando na mesma faixa obtida por Nicoleti (2001) para fatias de abacaxi desidratadas por ar quente. Esse autor também observou que as amostras com tratamento osmótico apresentaram menores índices de reidratação. Os efeitos das condições de congelamento das fatias antes da liofilização podem ser mais bem observados através do gráfico de superfície apresentado na Figura 23. Como 
mostra a Tabela 11, ambos os efeitos lineares (L) e quadráticos (Q) da espessura das fatias e da temperatura de congelamento foram significativos ao nível $95 \%(\mathrm{p}<0,05)$.

Tabela 10. Capacidade de reidratação de fatias de abacaxi liofilizadas submetidas a diferentes condições de congelamento e condicionadas a $\mathrm{a}_{\mathrm{w}}=0,432$.

\begin{tabular}{cccc}
\hline $\begin{array}{c}\text { Taxa de } \\
\text { congelamento } \\
\left({ }^{\circ} \mathbf{C} / \mathbf{m i n}\right)\end{array}$ & $\begin{array}{c}\text { Espessura } \\
\text { da fatia } \\
(\mathbf{c m})\end{array}$ & $\begin{array}{c}\text { Temperatura de } \\
\text { congelamento } \\
\left({ }^{\circ} \mathbf{C}\right)\end{array}$ & $\begin{array}{c}\text { Índice de } \\
\text { reidratação }\end{array}$ \\
\hline 0,067 & 0,5 & -14 & 1,71 \\
0,054 & 1,0 & -14 & 1,37 \\
0,031 & 1,5 & -14 & 1,37 \\
0,135 & 0,5 & -24 & 1,25 \\
0,074 & 1,0 & -24 & 1,09 \\
0,067 & 1,5 & -24 & 1,08 \\
0,377 & 0,5 & -34 & 1,27 \\
0,220 & 1,0 & -34 & 1,14 \\
0,125 & 1,5 & -34 & 1,13 \\
\hline
\end{tabular}

Tabela 11. Análise de variância dos dados de reidratação em função da espessura da fatia e da temperatura de congelamento.

\begin{tabular}{lccccc}
\hline \multicolumn{1}{c}{ Fator } & SQ & GL & QM & F & p \\
\hline Temperatura (L+Q) & 0,153 & 2 & 0,076 & 33,3 & 0,003 \\
Espessura (L+Q) & 0,073 & 2 & 0,037 & 15,9 & 0,012 \\
Erro & 0,009 & 4 & 0,002 & & \\
SQ total & 0,235 & 8 & & & \\
\hline
\end{tabular}

SQ: Soma dos quadrados dos resíduos; GL: Graus de liberdade; QM: Quadrado médio.

Como mostra a Figura 22, o índice de reidratação foi maior para as maiores temperaturas de congelamento (menor taxa de congelamento), o que pode estar refletindo o 
efeito da maior destruição do tecido celular causada pelo congelamento mais lento. Esse comportamento está de acordo com os resultados observados para vários outros produtos liofilizados (HAMMAMI; RENÉ, 1997).

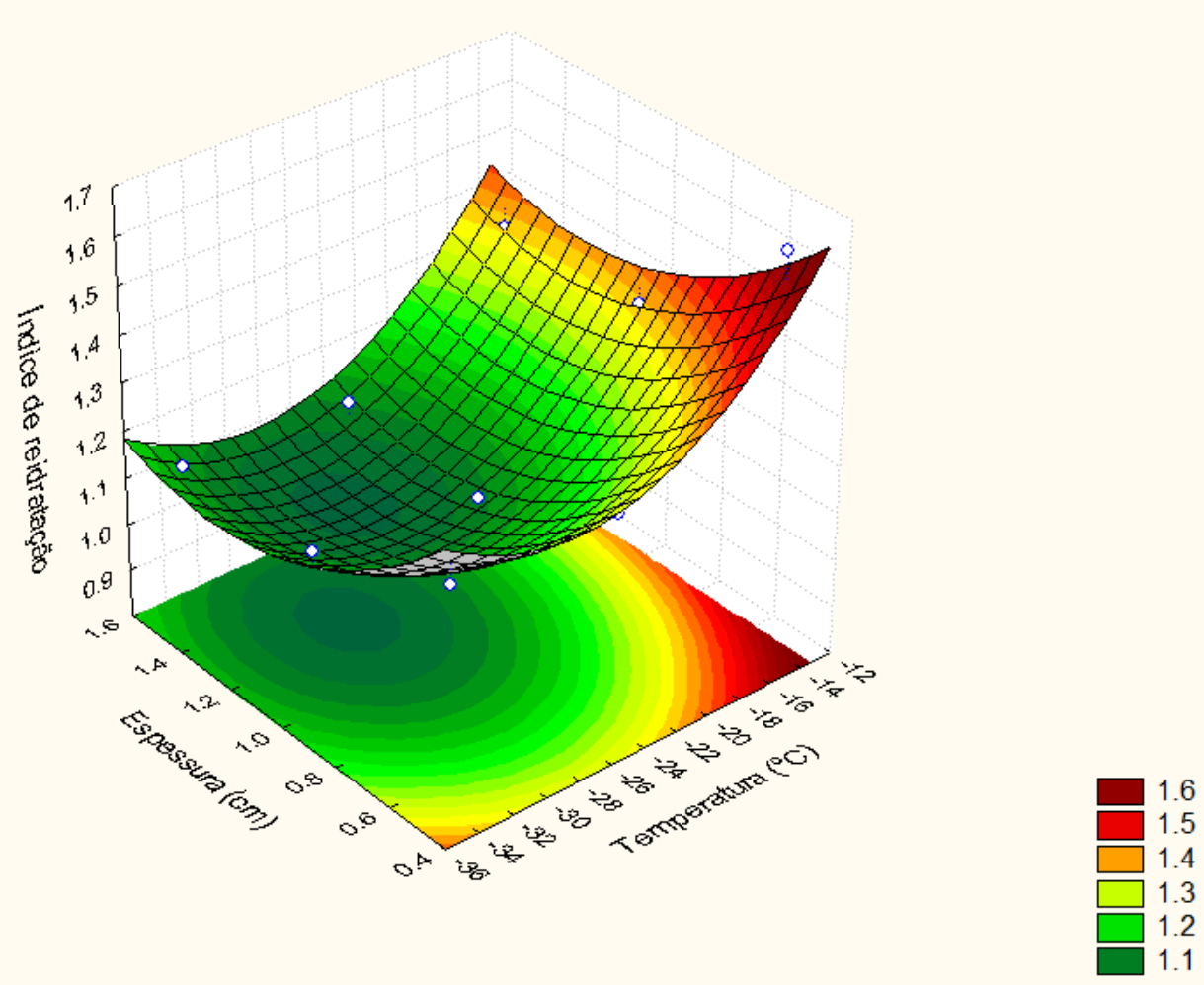

Figura 22. Efeitos da espessura das fatias e da temperatura de congelamento sobre o índice de reidratação das fatias de abacaxi liofilizadas e condicionadas a $\mathrm{a}_{\mathrm{w}}=0,432$.

Por outro lado, tais considerações não explicam o aumento do índice de reidratação observado com a redução da espessura das fatias, um comportamento contrário ao esperado, pois as fatias de menor espessura apresentaram as maiores taxas de congelamento. Esse comportamento contraditório poderia ser resultado da própria metodologia de reidratação adotada. Nesse caso, a etapa inicial de acondicionamento em umidade relativa constante, a qual já causou um certo grau de reidratação no produto, pode ter provocado o colapso 
estrutural das fatias ao longo do tempo, prejudicando a reidratação na etapa final. Marques, Prado e Freire (2009), estudando a cinética de reidratação de diferentes frutas tropicais liofilizadas, concluíram que o colapso do material observado durante o próprio processo de reidratação foi responsável pelos menores índices de reidratação atingidos ao final do mesmo.

\subsection{Textura}

A partir dos dados experimentais coletados no texturômetro, o programa Texture Expert V. 1.22 (Stable Micro Systems), calculou os diversos parâmetros que podem ser obtidos pelo teste de TPA. Para uma análise inicial do comportamento das fatias de abacaxi em função das condições de congelamento, selecionou-se o parâmetro dureza, cujos valores obtidos são apresentados na Tabela 12. Esses dados foram, então, submetidos à análise de variância, a qual demonstrou que apenas o efeito da espessura das fatias foi significativo ao nível de $95 \%(\mathrm{p}<0,05)$.

A Figura 23 apresenta um gráfico de superfície onde se pode visualizar o efeito das variáveis consideradas sobre a dureza das amostras. Observa-se uma tendência de maior dureza em amostras de espessura e temperatura de congelamento intermediário. De forma aproximada, pode-se considerar que as combinações de espessura e temperatura que resultaram em maior dureza são aquelas que apresentaram menor índice de reidratação. Este é um resultado que pode ser explicado pelo grau de colapso sofrido pelas amostras, seja durante a liofilização propriamente dita, seja pela etapa de acondicionamento em umidade relativa constante.

Tabela 12. Dureza de fatias de abacaxi liofilizadas submetidas a diferentes condições de congelamento e condicionadas $\mathrm{a}_{\mathrm{w}}=0,432$. 


\begin{tabular}{cccc}
\hline $\begin{array}{c}\text { Taxa de } \\
\text { Congelamento } \\
\left({ }^{\circ} \mathbf{C} / \mathbf{m i n}\right)\end{array}$ & $\begin{array}{c}\text { Temperatura de } \\
\text { congelamento } \\
\left({ }^{\circ} \mathbf{C}\right)\end{array}$ & $\begin{array}{c}\text { Espessura } \\
\text { da fatia } \\
(\mathbf{c m})\end{array}$ & $\begin{array}{c}\text { Dureza } \\
\mathbf{( N )}\end{array}$ \\
\hline 0.067 & -14 & 0,5 & 42,81 \\
0.054 & -14 & 1,0 & 146,8 \\
0.031 & -14 & 1,5 & 53,23 \\
0.135 & -24 & 0,5 & 207,8 \\
0.074 & -24 & 1,0 & 405,4 \\
0.067 & -24 & 1,5 & 68,76 \\
0.377 & -34 & 0,5 & 23,69 \\
0.220 & -34 & 1,0 & 352,2 \\
0.125 & -34 & 1,5 & 53,63 \\
\hline
\end{tabular}

Tabela 13. Análise de variância dos dados de dureza em função da espessura da fatia e da temperatura de congelamento.

\begin{tabular}{lccccc}
\hline \multicolumn{1}{c}{ Fator } & SQ & GL & QM & F & p \\
\hline Temperatura (L+Q) & 32368 & 2 & 16184 & 2,53 & 0,194 \\
Espessura (L+Q) & 104222 & 2 & 52111 & 8,15 & 0,039 \\
Erro & 25566 & 4 & 6392 & & \\
SQ total & 162156 & 8 & & & \\
Soma dos quadrados dos resíduos; GL: Graus de liberdade; QM: Quadrado médio.
\end{tabular}

De acordo com Hammami e René (1997), as condições de congelamento que mais bem preservam a textura de produtos liofilizados são as que oferecem altas taxas de congelamento. Esse efeito foi observado nos resultados deste trabalho, porém, a dureza também foi menor para amostras de maior espessura, o que não pode ser explicado através desse argumento.

Existem poucos trabalhos publicados sobre a textura de frutas liofilizadas em pedaços, sendo mais abundantes os trabalhos sobre liofilização de sucos e polpas de frutas, onde a textura tem menor importância. Isso dificulta a comparação com os resultados de outros autores. 


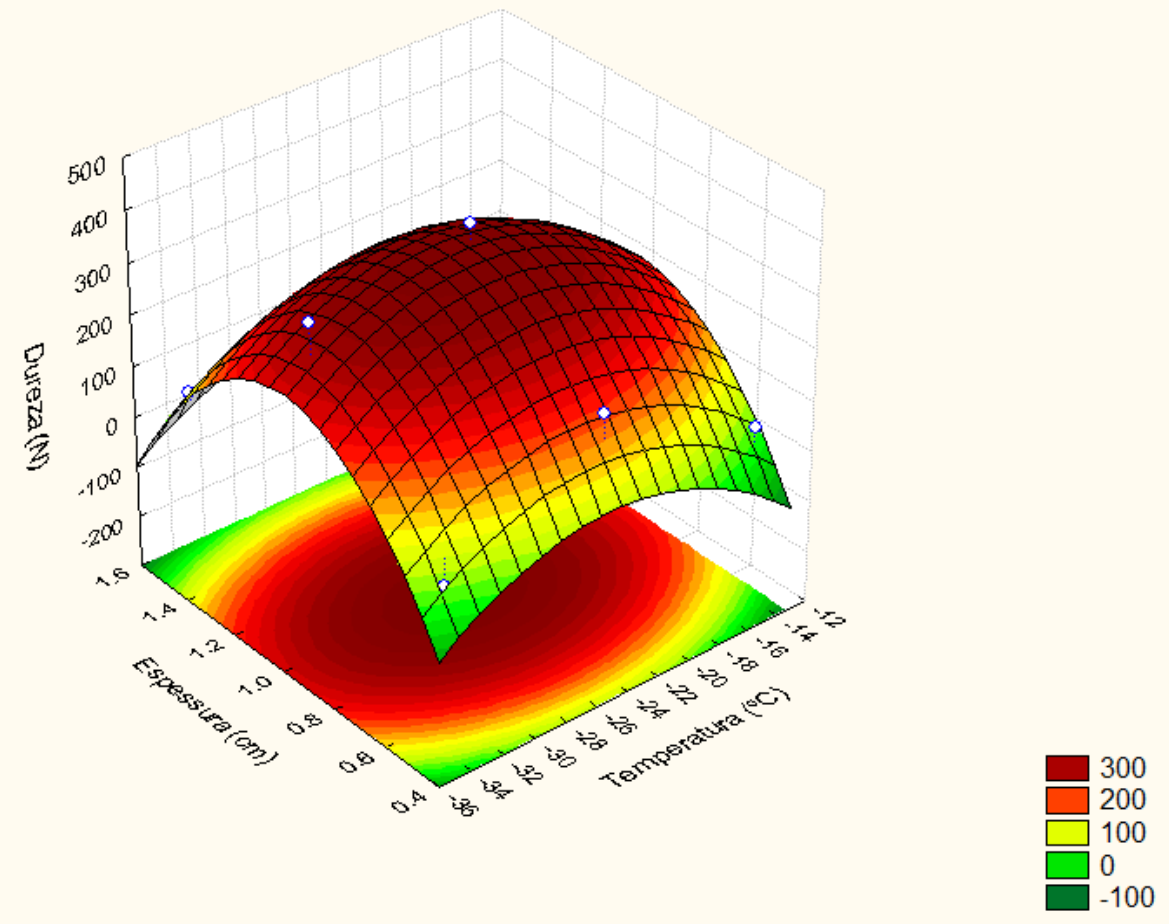

Figura 23. Efeitos da espessura das fatias e da temperatura de congelamento sobre a dureza das fatias de abacaxi liofilizadas e condicionadas em $\mathrm{a}_{\mathrm{w}}=0,432$. 


\section{CONCLUSÕES}

Os resultados do presente trabalho mostraram que existe uma forte dependência da cinética de secagem e dos atributos de qualidade de um produto liofilizado, especificamente fatias de abacaxi, em função das condições utilizadas durante a etapa de congelamento. Mesmo considerando que todas as condições de congelamento utilizadas levaram ao que se pode classificar de congelamento lento, pode-se observar diferenças significativas entre as variáveis dependentes avaliadas - difusividade efetiva, retenção de vitamina $\mathrm{C}$, reidratação e dureza - em função das taxas de congelamento empregadas.

Por outro lado, a taxa de congelamento não é a única variável que tem influência sobre a cinética de secagem e os atributos de qualidade. A combinação de temperatura e umidade, tanto durante a liofilização propriamente dita, quanto durante a etapa de reidratação tem influência sobre a transição vítrea do material que, por sua vez, afeta a extensão do colapso estrutural sofrido pelo produto.

Para obter resultados mais conclusivos, principalmente sobre o índice de reidratação e parâmetros de textura do produto, é imprescindível que se realize um estudo mais detalhado do processo de reidratação, incluindo a cinética de reidratação e a avaliação do encolhimento e da porosidade do produto. 


\section{SUGESTÕES PARA TRABALHOS FUTUROS}

1. Realizar estudos similares com outras frutas, preferencialmente com uma estrutura mais regular que o abacaxi, uma vez que a estrutura fibrosa e irregular deste último pode afetar os resultados.

2. Comparar a retenção de vitamina $\mathrm{C}$ das mesmas frutas quando desidratadas por ar quente e por liofilização.

3. Aperfeiçoar a metodologia de análise da reidratação, incluindo a avaliação da cinética de ganho de água em função das condições de reidratação.

4. Avaliar a porosidade e o encolhimento dos produtos liofilizados após diferentes condições de congelamento e correlacionar com a cinética de desidratação e atributos de qualidade.

5. Avaliar o consumo energético do processo em função das variáveis independentes estudadas, tanto no congelamento quanto na liofilização. 


\section{REFERÊNCIAS BIBLIOGRÁFICAS}

ABANORTE - Associação Central dos Fruticultores do Norte de Minas, Disponível em: $<\underline{\text { http://www.abanorte.com.br/noticias/abacaxi-importancia-economica-e-nutricional- }>}$ Acesso em 17 de Dezembro de 2009

ALDRIGUE, M. L.; MADRUGA, M. S.; FIOREZE, R.; LIMA, A. W. O.; SOUSA, C. P. Aspecto da ciência e tecnologia de alimentos. Ed. UFPB, v. 1, João Pessoa, 198p. 2002.

ALMEIDA, P.; MEIRA, T.; ALENCAR, L. C.; FREITAS, A.; HERCULANO, L. Avaliação físico-química de pós - alimentícios de manga (Mangifera indica L.) de diferentes variedades obtidos pelo processo de liofilização. Anais do IX ENPPG, IX ENICIT, III SIMPIT, Instituto Federal de Educação, Ciência e Tecnologia do Ceará, 2009, Disponível em: $<$ http://www.intv.ifce.edu.br/eventos2009/viewpaper.php?id=424\&cf=1 $>$ Acesso em $21 \mathrm{de}$ janeiro de 2010.

ALVES-FILHO, O.; STROMMEN, I. The application of heat pump in drying of biomaterials. Drying Technology, v. 14, n. 9, p. 2061-2090, 1996.

BAGLEY, E.B.; CHRISTIANSON, D.D. Measurement and interpretation of rheological properties of foods. Food Technology-Chicago, v. 41, n. 3, p. 96-99, 1987.

BENASSI, M. T.; ANTUNES, A. J. A comparison of meta-phosphoric and oxalic acids as extractant solutions for the determination of vitamin $\mathrm{C}$ in selected vegetables. Arquivos de Biologia e Tecnologia, v. 34, n. 4, 507-513, 1988.

BHANDARI, B.R.; HOWES, T. Implication of glass transition for the drying and stability of dried foods. Journal of Food Engineering, v. 40, n. 1-2, p. 71-79, 1999.

BOSS, E. A. Modelagem e otimização do processo de liofilização: aplicação para leite desnatado e café solúvel. 2004. 107p. Tese (Doutorado em Engenharia Química). Faculdade de Engenharia Química, Universidade Estadual de Campinas, 2004.

BOUDHRIOUA, N.; MICHON, C.; CUVELIER, G.; BONAZZI, C. Influence of ripeness and air temperature on changes in banana texture during drying. Journal of Food Engineering, v. 55, p. 115-121, 2002. 
CHAVES, M. C. V.; AlMEIDA, J. P. G. G. F. A. C.; LEITE, J. C. A.; SILVA, F. L. H. Caracterização físico-química do suco da acerola. Revista de Biologia e Ciências da Terra, v. 4, n. 2, 2004.

CHEN, T.; OAKLEY, D.M. Thermal analysis of proteins of pharmaceutical interest. Thermochimica Acta, v. 248, p. 229-244, 1995.

COLLA, L. M.; HERNÁNDEZ, C. P. Congelamento e descongelamento e sua influência sobre os alimentos. Vetor, Rio Grande, v. 13, p. 53-66, 2003.

CRANK, J. The mathematics of diffusion. Pergamon Press, Oxford, 1975.

EMBRAPA, $2009 . \quad$ Disponível em: <www.cpafro.embrapa.br/embrapa/Artigos/frut brasil.html $>$ Acesso em 17 de Dezembro de 2009.

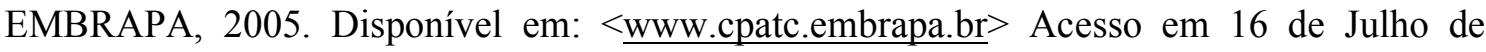
2008 .

FAO, 2009. $\quad$ FAOSTAT. Disponível em: $<$ http://faostat.fao.org/site/567/DesktopDefault.aspx\#ancor> Acesso em 16 de Outubro de 2009.

FENNEMA, O. R. Loss of vitamins in fresh and frozen foods, Food Technology, v. 31, n.12, p. 32, 1977.

FERREIRA, D.; SILVA, J. A. L.; PINTO, G.; SANTOS, C.; DELGADILLO, I.; COIMBRA, M. A. Effect of sundrying on microstructure and texture of S. Bartolomeu pears (Pyrus communis L.). European Food Research and Technology, v. 226, p. 1545-1552, 2008.

GABAS, A. L.; MENEGALLI, F. C.; FERRARI, F.; TELIS-ROMERO, J. T. Influence of drying conditions on the rheological properties of prunes. Drying Technology, v. 20, n. 7, p. 1485-1502, 2002.

GABAS, A. L.; MENEGALLI, F. C.; TELIS-ROMERO, J. T. Effect of chemical pretreatment on the physical properties of dehydrated grapes. Drying Technology, v. 17, n. 6, p. 1215-1226, 1999. 
GUIMARÃES, O. M.; KUWABARA, I. H., Determinação de ácido ascórbico em produtos alimentícios. In: Química e Sociedade, Manual do Professor, pp. 41-56. Universidade Federal do Paraná, 2004. Disponível em: $<$ http://www.quimica.ufpr.br/eduquim/pdf/experimento3.pdf $>$. Acesso em 17 de Dezembro de 2009.

HAMMAMI, C.; RENÉ, F. Determination of freeze-drying process variables for strawberries. Journal of Food Engineering, v. 32, p. 133-154, 1997.

HAWLADER, J. N. A.; UDDIN, M. S.; HO, J. C.; TENG, A. B. W. Drying characteristics of tomatoes. Journal of Food Engineering, v. 14, p. 25-268, 1991.

IBARZ, A.; BARBOSA-CANOVAS, G. V. Deshidratación In Operaciones Unitarias en la Ingeniaría de Alimentos Lancaster, Basel, 1999.

JAYARAMAN, K. S.; DAS GUPTA, D. K. Drying of fruits and vegetables. In: MUJUNDAR, A. S. Handbook of Industrial Drying New York: Marcel Dekker, p. 672-680, 1995.

KALRA, C. L.; BEERH, O. P.; MANAN, J. K.; TEOTIA, M. S.; SHARMA, T.C. Studies of the influence of cultivars on the quality of dehydrated onion. Indian Food Packer, v. 40, n. 4, p. 20-27, 1986.

KOCHS, M.; KORBER, C. H.; HESCHEL, I.; NUNNER, B. The influence of the freezing process on vapour transport during sublimation in vacuum freezing-drying of macroscopic samples. International Journal of Heat and Mass Transfer, v. 36, p. 1727-1738, 1993.

KOROISHI, E. T. Estudo do processo de liofilização: aplicação para suco de laranja. 2005. 156p. Tese (Mestrado em Engenharia Química). Faculdade de Engenharia Química, Universidade Estadual de Campinas, 2005.

LEVI, A.; BEM-SHALOM, N.; PLAT, D.; REID, D. S. Effect of blanching and drying on pectin constituents and related characteristics of dehydrated peaches. Journal of Food Science, v. 53, p. 1187-1190, 1988.

LUND, D. B. Food engineering for the $21^{\text {st }}$ century. In: CHANES, J. W.; CANOVAS, G. V. B.; AGUILERA, J. M. Engineering and Food for the $21^{\text {st }}$ Century, p. 3-5, Boca Raton, London, New York, Washington, 2002. 
MADRAU, M. A.; PISCOPO, A.; SANGUINETTI, A. M.; DEL CARO, A.; POIANA, M.; ROMEO, F. V.; PIGA, A. Effect of drying temperature on polyphenolic content and antioxidant activity of apricots. European Food Research and Technology, V. 228, n. 3, p. 441-448, January, 2009.

MARFIL, P. H. M.; SANTOS, E. M.; TELIS, V. R. N. Ascorbic acid degradation kinetics in tomatoes at different drying conditions. Food Science and Technology / LebensmittelWissenschaft Technologie, v. 41, p. 1642-1647, 2008.

MARQUES, L. G.; FERREIRA, M. C.; FREIRE, J. T. Freeze drying of acerola (Malgiphia glabra L.). Chemical Engineering and Processing, v. 46, p. 451-457, 2007.

MARQUES, L. G.; PRADO, M. M.; FREIRE, J. T. Rehydration characteristics of freeze dried tropical fruits. Food Science and Technology. V. 42, p. 1232-1237, 2009.

MC CORMICK, P. Y. Solids drying fundamentals. In: PERRY, R. H.; CHILTON, C. H. Chemical Engineer's handbook. Mc Graw-Hill Co., 5 ed., Sec. 20-4, 1983.

MEDINA, J. C.; BLEINROTH, E. W.; MARTIN, Z. J.; JUNIOR, A. J. S.; LARA, J. C. C.; HASHIZUME, T.; MORETTI, V. A.; MARQUES, J. F. Frutas Tropicais 2 Abacaxi p. 5, 6,21, 91, 135-145, Governo do Estado de São Paulo, Secretaria da Agricultura, Coordenadoria da Pesquisa Agropecuária, Instituto de Tecnologia de Alimentos, 1978.

MINISTÉRIO DA AGRICULTURA, PECUÁRIA E ABASTECIMENTO. Agricultura brasileira em números. Anuário 2005. Disponível em: < $\underline{\mathrm{http}} / / / \mathrm{www}$.agricultura.gov.br/ $>$ Acesso em 24 de janeiro de 2010.

MORGADO, R. H.; ABREU, J. D. A. Textura de sólidos y semisolidos. In Métodos para medir propriedades físicas em Industria de Alimentos. Ed Alvarado, J. D. Aguilera, J. M. Zaragoza, Ed Acribia. 410p. 2001.

MPSC INFORMAÇÕES TÉCNICAS. Água: retirando dos alimentos. Disponível em: http://www.mspc.eng.br/tecdiv/topDiv110.shtml Acesso em 26 de janeiro de 2010.

MURGATROYD, K.; BUTLER, L. D.; KINNARNEY, K.; MONGER, P. Good pharmaceutical freeze-drying practice, Peter Cameron (ed.), 1997.

NAKAGAWA, K.; HOTTOT, A.; VESSOT, S.; ANDRIEU, J. Modeling of freezing step during freeze-drying of drugs in vials. Bioengineering, Food, and Natural Products, v. 53, n. 5, p. 1362-1372, 2007. 
NICOLETI, J. F. Cinética de secagem e encolhimento de fatias de abacaxi. 106p. Dissertação (Mestrado), Universidade Estadual Paulista, São José do Rio Preto, 2001.

NICOLETI, J. F.; SILVEIRA JUNIOR, V.; TELIS-ROMERO, J.; TELIS, V. R. N. Ascorbic acid degradation during convective drying of whole persimmons as affected by drying conditions. Drying Technology, v. 25, p. 891-899, 2007.

NICOLETI, J. F.; SILVEIRA JUNIOR, V.; TELIS-ROMERO, J.; TELIS, V. R. N. Viscoelastic behavior of persimmons dried at constant air temperature. Food Science and Technology / Lebensmittel-Wissenschaft Technologie, v. 38, n. 2, p. 143-150, 2005.

NICOLETI, J. F.; TELIS-ROMERO, J.; TELIS, V. R. N. Air-drying of fresh and osmotically pre-treated pineapple slices: fixed air temperature versus fixed slice temperature drying kinetics. Drying Technology, v. 19, p. 2175-2191, 2001.

NIJHUIS, H. H.; TORRINGA, E.; LUYTEN, H.; RENÉ, F.; JONES, P.; FUNEBO, T.; OHLSSON, T. Research needs and opportunities in the dry conservation of fruits and vegetables. Drying Technology, v. 14, n. 6, p. 1429-1457, 1996.

OGWAL, M.; DAVIS, D. R. Rapid rehydration method for dried beans. Journal of Food Science, v. 59, p. 611-612, 1994.

OLIVEIRA, R. A.; OLIVEIRA, W. P.; PARK, K. J. Determinação da difusividade efetiva de raiz de chicória. Engenharia Agrícola, Jaboticabal-SP, v. 26, n.1, p. 181-189, Jan/Abr., 2006

ORREGO-ALZATE, C. E. Congelación y Liofilización de Alimentos, Universidad Nacional de Colombia, Manizales, 172 p. 2008.

PARK, K. J.; YADO, M. K. M.; BROD; F. P. R. Estudo de secagem de pêra Bartlett (Pyrus sp.) em fatias. Ciência e Tecnologia de Alimentos, Campinas, v. 21, n. 3, p. 288-292, 2001.

QUEIROZ, V. A. V.; BERBERT, P. A.; MOLINA, M. A. B.; GRAVINA, G. A.; QUEIROZ, L. R.; SILVA, J. A. Qualidade nutricional de goiabas submetidas aos processos de desidratação por imersão-impregnação e secagem complementar por convecção. Ciência e Tecnologia de Alimentos, v. 28, n. 2, 2008. 
RAO, V. N. M.; DELANEY, R. A. M.; SKINNER, G.E. Rheological properties of solid foods. In Engineering Properties of Foods; RAO, M. A.; RIZVI, S. S. H., Ed Marcel Dekker: New York, 55-97, 1995.

RIZVI, S. S. H. Thermodynamic properties of foods in dehydration. Engineering Properties of Foods, 2nd ed. (M.A. Rao e S.S.H. Rizvi, eds.) p. 223-310, Academic Press: New York, 1995.

RODRIGUES, A. E. Desidratação Osmótica e Secagem de Maçãs. Dissertação (Mestrado), Universidade Estadual Paulista, São José do Rio Preto, 2003.

SAVITCI, L. A.; GASPARINO FILHO, J.; LEITE, R. S. S. F.; BLISKA, F. M. M. Packing house e mercado para abacaxi. Boletim do CEPPA, v. 14, p. 181-204, 1996.

SINGH, R. P.; HELDMAN, D. R. Introducción a la Ingeniería de los Alimentos. Zaragoza: Acríbia, 544p, 1998.

SNOWMAN, J. W. Freeze Dryers In BAKER, C. G. J. Industrial Drying of Foods, p. 134145, London, Weinheim, New York, Tokyo, Melbourne, Madras, 1997.

STADLER, Z. Determinação do Teor de Vitamina C em Alimentos. Monografia apresentada ao Curso de Especialização em Ensino de Química Experimental para o 20. Grau, Setor de Ciências Exatas, Departamento de Química, Universidade Federal do Paraná. Curitiba, 27f, 1999.

STRUMILLO, C.; ADAMIEC, J. Energy and quality aspects of food drying. Technical Univ. of Lodz (Poland). Faculty of Process and Environmental Engineering. Drying Techonology, v. 14, p. 423-448, 1996.

TATTINI JUNIOR, V.; PARRA, D. F.; PITOMBO, R. N. M. Influência da taxa de congelamento no comportamento físico-químico e estrutural durante a liofilização da albumina bovina. Revista Brasileira de Ciências Farmacêuticas, vol. 42, n. 1 São Paulo Jan/Mar. 2006.

TELIS, V. R. N.; TELIS-ROMERO, J.; GABAS, A. L. Solids rheology for dehydrated food and biological materials. Drying Technology, v. 23, n. 4, p. 759-780, 2005.

TODA FRUTA, 2008 Disponível em: <www.todafruta.com.br> Acesso em 16 de Agosto de 2008 . 
US Department of Agriculture, 2008 Disponível em: $\leq$ http://www.nal.usda.gov/fnic/foodcomp $>$ Acesso em 16 de Agosto de 2008.

VITAL, A.; LUZ, F.; LIMA, M. Secagem - Liofilização, Fevereiro, 2003. Disponível em: $\leq$ http://www.ufrgs.br/Alimentus/feira/opconser/liof.htm $>$ Acesso em 21 de Janeiro 2010.

WOJDYLO, A.; FIGIEL, A.; OSZMIANSKI, J. Effect of drying methods with the application of vacuum microwaves on the bioactive compounds, color, and antioxidant activity of strawberry fruits. Journal of Agricultural and Food Chemistry, v. 57, n. 4, p. 1337-1343, 2009. 